\title{
Notes on the genera Aristopus, Cosmodiscus and Metabacetus (Coleoptera: Carabidae: Pterostichini: Abacetina), with description of three new species from Vietnam
}

\author{
Заметки о родах Aristopus, Cosmodiscus и Metabacetus (Coleoptera: \\ Carabidae: Pterostichini: Abacetina) с описанием трёх новых видов \\ из Вьетнама
}

D.N. Fedorenko

A.H. Федоренко

\begin{abstract}
A.N. Severtsov Institute of ecology and evolution, Leninsky pr. 33, Moscow 119071, Russia.
Институт проблем экологии и эволюции им. А.Н. Северцова, Российская Академия Наук, Ленинский пр-т 33, Москва 119071, Россия. E-mail: dmitri-fedorenko@yandex.ru
\end{abstract}

KEY WORDS: Coleoptera, Carabidae, Pterostichini, new species, new synonymy, Vietnam.

КЛЮЧЕВЫЕ СЛОВА: Coleoptera, Carabidae, Pterostichini, новый вид, новая синонимия, Вьетнам.

ABSTRACT. Three abacetine genera (Coleoptera, Carabidae, Pterostichini), Aristopus LaFerté-Sénectère, 1853, Cosmodiscus Sloane, 1907 (= Celioinkosa Straneo, 1951, syn.n.), and Metabacetus Bates, 1892, and their ten Oriental species, are reviewed. Three new species, $A$. humeratus sp.n., C. rufoapicalis sp.n., and C. sharovae sp.n., all from Vietnam, are described. Aristopus picturatus (Andrewes, 1920), comb.n., is transferred from Cosmodiscus to Aristopus; Caelostomus kaszabi (Jedlička, 1954) and Cosmodiscus latus Andrewes, 1947 are provisionally placed within Aristopus. Key to the Oriental species of Aristopus and Cosmodiscus is provided.

РЕЗЮМЕ. Дан обзор 3 родов трибы Abacetina (Coleoptera, Carabidae, Pterostichini), Aristopus LaFertéSénectère, 1853, Cosmodiscus Sloane, 1907 (= Celioinkosa Straneo, 1951, syn.n.), Metabacetus Bates, 1892, и 10 видов этих родов из Ориентальной области. Из Вьетнама описаны 3 новых вида: A. humeratus sp.n., C. rufoapicalis sp.n. и C. sharovae sp.n. Aristopus picturatus (Andrewes, 1920), comb.n. переведён в соответствующий род из рода Cosmodiscus; Caelostomus kaszabi (Jedlička, 1954) и Cosmodiscus latus Andrewes, 1947 предварительно помещены в род Aristopus. Coставлена определительная таблица ориентальных видов Aristopus и Cosmodiscus.

\section{Introduction}

In the Oriental region, the subtribe Abacetina (Carabidae, Pterostichini) is known to be represented by six genera. Among them, Abacetus Dejean, 1828, is polytypical and largely Paleotropical in distribution. It is well-defined by the antennal pedicel eccentrically articulated to the scape, whereas the other five genera, Metabacetus Bates, 1892; Cosmodiscus Sloane, 1907; Holconotus Schmidt-Göbel, 1846; Tiferonia Darlington, 1962; and Mateuellus Deuve, 1990, all share the antennal pedicel centrically inserted in the scape; most of them being oligotypic and also widespread. Another genus, Melanchrous Andrewes, 1940, still remains enigmatic and placed within either Pterostichini or Licinini. Based on many characters examined, including genital structures of both sexes and reproductive tract of the female, I suppose that Melanchrous may belong to the tribe Perigonini rather than to any other tribe of the Carabidae.

Metabacetus includes eight described and four undescribed species [Will, Park, 2008; Guéourguiev, 2013], all rare in collections and ranging combined from India to the Sunda Isles and the Philippines. Cosmodiscus includes six Oriental, one Papuan, and one Australian species; a little-known Drimostoma kaszabi Jedlička, 1954 from Taiwan is certain to belong here as well. Will [2020b] has just supposed that Cosmodiscus may be a junior synonym of the Afrotropical and Madagascan genus Aristopus LaFerté-Sénectère, 1853 (=Celioschesis Tschitschérine, 1898), with no formal synonymy being established. Holconotus and Tiferonia were treated as closely related genera [Darlington, 1962; Will, 2020a, b].

In this paper, we review representatives of $\mathrm{Me}$ tabacetus, Cosmodiscus and Aristopus from the Orien-

How to cite this article: Fedorenko D.N. 2021. Notes on the genera Aristopus, Cosmodiscus and Metabacetus (Coleoptera: Carabidae: Pterostichini: Abacetina), with description of three new species from Vietnam // Russian Entomol. J. Vol.30. No.4. P.413-429. doi: 10.15298/rusentj.30.4.05 
tal region, chiefly Vietnam, and briefly discuss relations between the latter two genera, based on some characters of the adults, mostly genital ones and body setation.

Acronyms used are as follows: MPSU - the Moscow Pedagogical State University; SIEE — the author's reference collection at A.N. Severtsov Institute of Ecology \& Evolution, Russian Academy of Sciences, Moscow; NHML - Natural History Museum, London; ZISP - Zoological Institute, Russian Academy of Sciences, St. Petersburg; ZMMU — Zoological Museum of the Moscow State University; ZSM - Siberian Zoological Museum, Novosibirsk.

The following parameters and ratios were analyzed: maximum body length measured between apices of closed mandibles and sutural angle of elytra (BL); length of elytron, measured from the highest point of basal margin to sutural angle (EL); maximum width of elytra (EW); width of head across eyes (HW); length of eye in sagittal plane; width of pronotum between apical (PA) or basal (PB) angles; length of pronotum along median line (PL); distance between pronotal apex and level of maximum width of pronotum, measured along mid-line (PLw); maximum width of pronotum (PW). The measurements were taken using an eyepiece micrometer, to two decimal places. The means are given in round brackets for the ratios. Data on labels of type specimens are in quotes; slash shows new line. All labels are printed, with handwritten text given in italics.

\section{Results}

Metabacetus Bates, 1892

Bates, 1892: 364; Straneo, 1938a: 151; Will, Park, 2008: 191. Type species: Metabacetus immarginatus Bates, 1892 (by monotypy).

DIAGNOSIS. Macropterous species of small size (BL 5$8.5 \mathrm{~mm}$ ), uniform black, with antennal pedicel centrically inserted in scape, antennomeres 4-11 pubescent, pedicel glabrous but ventral seta, mentum pits well-developed, body integuments impilose, metatibia externally glabrous, pronotum impunctate, elytral interval 3 without discal setigerous pores, except for vestigial setigerous pore $\mathrm{d} 2$ (median) that lacks seta.

REDESCRIPTION. With characters of other Abacetina: frontal impressions sulciform, divergent towards anterior supra-ocular seta; pronotum with one, sulciform, basal fovea on each side; elytral parascutellar striole 'missing' (i.e., directly extended into stria 1 that lost its primary angular base); mesoventrite with medial groove to receive subcarinate posterior inclination of prosternal process; abdominal sternites not basally sulcate; metacoxa bisetose (inner seta missing), metatrochanter with seta; supra-ocular groove often directly extended into orbital groove (that between gena and neck).

Body (Figs 1-3) convex, uniform black, dorsum mostly iridescent and slightly sericeous due to dense and very transverse microsculpture, body appendages and extreme lateral margins of both pronotum and elytra red. Body setation nearly complete.

Head rather small, without neck constriction; eyes large, almost hemispherical, nearly reaching maxillary grooves be-

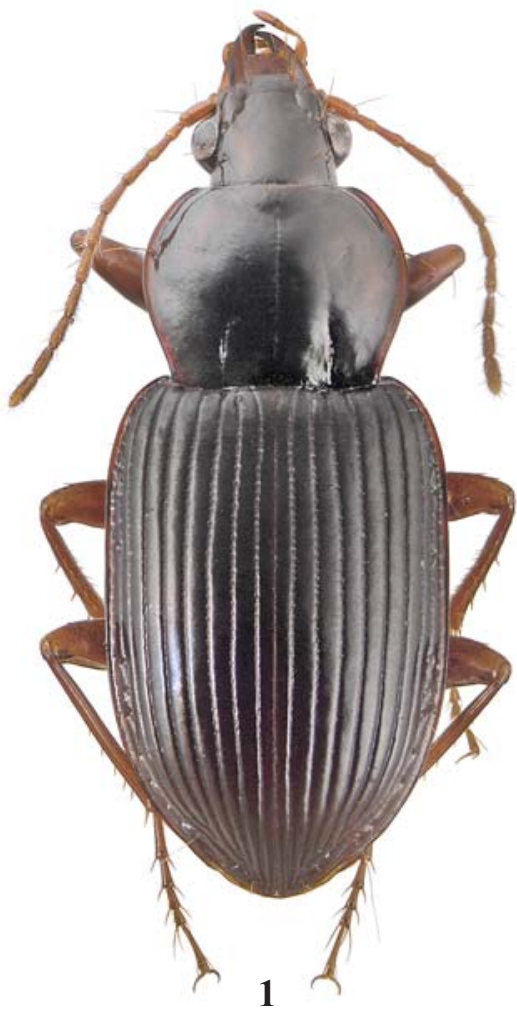

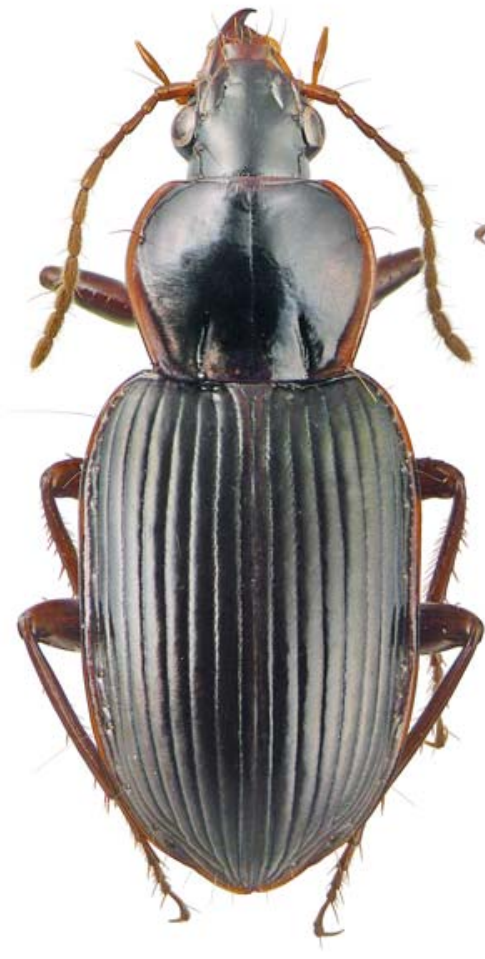

2

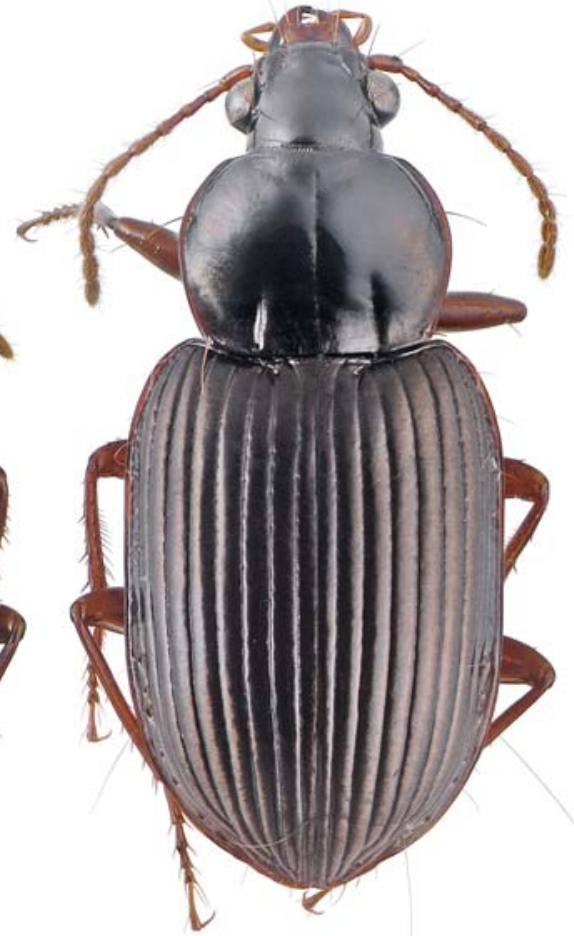

3

Figs 1-3. Dorsal habitus of Metabacetus spp.: $1-$ M. hermanni, $0^{\top}$ from Xuan Son NP; 2 - M. laotinus,, from Cao Bang Province; $3-$ M. perakianus, $q$ from Song Thanh NP.

Рис. 1-3. Габитус дорзально Metabacetus spp.: $1-$ M. hermanni, ơ из Национального парка Суансон; $2-$ M. laotinus, 9 из провинции Каобанг; 3 - M. perakianus,, из Национального парка Сонгтхань. 
neath; genae fairly long, smooth, subtransverse, meeting neck at sharp obtuse angle, anteroventrally without antennal grooves; frontal sulci reaching level of anterior supra-ocular seta, posteriorly diverging or slightly S-shaped at the seta. Labrum mostly subsinuate at apical margin. Mandibles rather long, narrow and slightly incurved apically, with ventral scrobal ridge straight or subconvex. Apical maxillary and labial palpomere fusiform. Mentum tooth triangular, narrowly rounded, faintly longitudinally grooved. Setation: two supraocular setae and one clypeal seta on each side; labrum sexsetose; submentum quadrisetose, mentum bisetose.

Pronotum quadrisetose, subquadrate. Sides rounded, finely beaded, subsinuate or straight in front of obtuse yet sharp basal angles, these with minute, almost imperceptible, blunt tooth; lateral margin distinctly explanate and reflexed or not. Base laterally oblique, without bead; apical bead obliterate in middle 1/5-1/3; basal transverse impression missing, apical

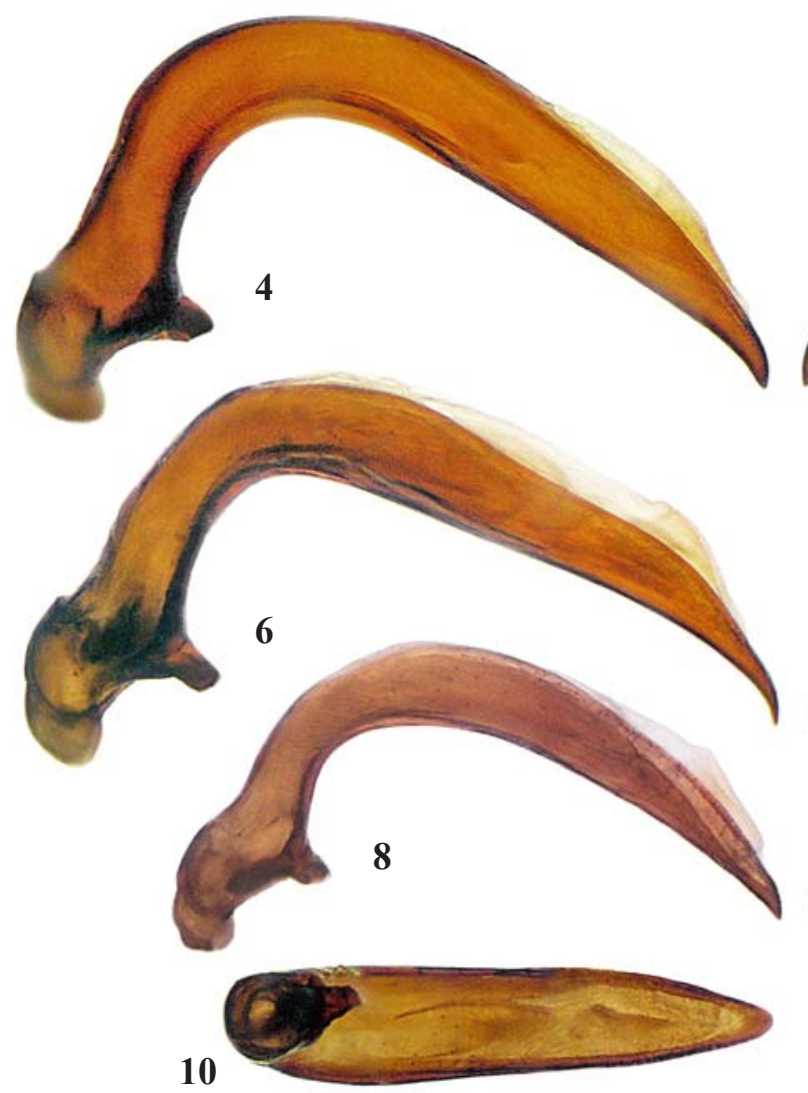

10

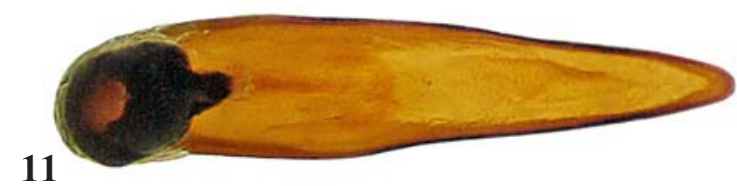

11

12

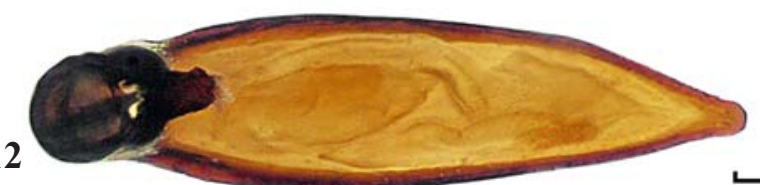

one vague. Basal sulci narrow, deep, smooth to crenulate at bottom, slightly converging apicad, reaching base, and running on basal third.

Elytra parallel-sided, truncate basally, with distinct humeri, a nearly imperceptible humeral tooth and a slight preapical sinuation. Basal ridge entire, humeral angle obtuse or very so. Striae entire, deep, more or less distinctly punctate, stria 7 separately reaching apex, stria 8 adjoining humerus or lateral margin just outside. Intervals 8 and 9 subequally wide except basally, interval 9 with umbilical seta series (USS) consisting of 6-1-7 umbilical setae/setigerous pores (US), i.e., six US in anterior group, seven $(3+2+2)$ in posterior group, and one intermediate seta. Parascutellar seta at base of stria 2. Stria 7 with two setae before apex, apical one being smaller than preapical.

Ventral side: prosternum with median groove distinct or not, prosternal process not bordered. Metepisternum longer than wide. Metaventrite laterally and abdominal sternite II rather

Figs 4-18. Aedeagus of Metabacetus spp.: 4-5, 11, 15-16-M. hermanni; 6-7, 12, 17-18 - M. laotinus; 8-14-M. perakianus; 4-12 - median lobe; 13, 15, 17 - right paramere; 14, 16, 18 - left paramere; 4, 6, 8, 13, 15, 17 — left aspect; 5, 7, 9, 14, 16, 18 - right aspect; 10-12 - ventral aspect; $\boldsymbol{v} \boldsymbol{c}$ - ventral longitudinal carina. Scale bar: $1 \mathrm{~mm}$.

Рис. 4-18. Эдеагус Metabacetus spp.: 4-5, 11, 15-16-M. hermanni; 6-7, 12, 17-18 - M. laotinus; 8-14 - M. perakianus; 4-12 — средняя доля; $13,15,17$ - правая парамера; $14,16,18$ - левая парамера; 4, 6, 8, 13, 15, 17 - слева; 5, 7, 9, 14, 16, 18 - справа; 10-12 - вентрально; $\boldsymbol{v c}$ - продольный вентральный киль. Масштаб: 1 мм. 
densely punctate; mesepisterna basally, metepisterna, and sides of abdominal sternites III-V less distinctly so. Sternites IV-VI with one pair of obligatory paramedian setae. Sternite VII bisetose in male, quadrisetose in female, all setae marginal.

Legs slender, protibia not apically dilated, with two close lateroapical setae (spinules), apical seta being stronger than preapical. Setation otherwise as follows: Profemur without anterior (anteroventral) setae, with three posterior setae, basal, medioventral, and apical. Mesotibia with lateral armature consisting of moderately strong spiniform setae, 3-4 anterolateral and one posterolateral near distal anterolateral seta (not counting apical setae); inner setal brush (at posteromesal margin) continuous and nearly unspecialized, consisting of ca. 16 setae. Metatibia externally glabrous. Meso- and metatarsi with tarsomere 1 externally (anteriorly) sulcate and slightly shorter than tarsomeres 2 to 4 combined, without distinct lateral setae. Tarsomere 5 ventrally glabrous, dorsal (dorsolateral) seta almost median in position; tarsomeres 1 and 2 with dorsoapical setae (DAS), these being much shorter in metatarsi; pro- and mesotarsomere 4 with lamellate ventroapical setae. Basal three protarsomeres dilated and biserially squamose in male, basal two protarsomeres toothed at latero-apical angles in female.

Aedeagus (Figs 4-18): median lobe geniculate, with a well-developed longitudinal median carina in ventral curve; apex short, narrow, more or less triangular; internal sac unarmed. Parameres subequal in length, right one apically rounded and spoon-shaped.

Tergite VIII and sternite VIII in female as in Figs 26-26. Female genitalia (urite IX) and reproductive tract (examined in $M$. hermanni): laterotergite ventrally with a long process which is directed apicad and bears a brush of longer setae at apex (Fig. 34); gonosubcoxite at apex with 2-3 very short, dense, apically blunt, setae; gonocoxite slender, crescent, as long as gonosubcoxite, with a small ensiform, apically blunt, ventral (outer) seta a third from base and double preapical nematiform seta, no dorsal setae; bursa copulatrix membranous, spermatheca convoluted and very long, consisting of ca. 60 tight turns.

GEOGRAPHIC DISTRIBUTION. Throughout the Oriental region.

HABITATS AND HABITS. Many adults of the three species reviewed below were collected at light at night, at the edges of broad-leaved monsoon forests at $600-1.450 \mathrm{~m}$ altitudes. Those of the most common species $M$. hermanni occur in montane regions of Vietnam at $400-1.700 \mathrm{~m}$ altitudes where they dwell in forest leaf-litter.

COMMENTS. Will and Park [2008] stated that most characters of Metabacetus are symplesiotypic while they described well-developed mentum pits, apparently apotypic character, for at least M. hermanni Will, 2008. The fact that these pits have been reported [Guéourguiev, 2013] for $M$. willi Guéourguiev, 2013, and found in M. laotinus Straneo, 1938 and M. perakianus Straneo, 1938, suggests monophyletic origin of the genus.

Another apotypic feature of Metabacetus, the elytra without discal setae, should be corrected because vestigial $\mathrm{d} 2$ has been found in all of the three species examined by me. It is very minute and thence hard to detect in $M$. hermanni, but more or less well traceable in M. laotinus and M. perakianus.

\section{Metabacetus hermanni Will et Park, 2008}

Figs 1, 4-5, 11, 15-16, 25-26, 34.

Will, Park, 2008: 191 (Ha Tinh Province, Vietnam).

MATERIAL. 50 specimens (SIEE): Vietnam, leg. D. Fedorenko: $110^{7} \sigma^{7}, 14$ 우, Phu Tho Province, $\sim 90 \mathrm{~km} \mathrm{~W}$ of Hanoi, Xuan Son National Park, $21^{\circ} 07^{\prime} 52^{\prime \prime} \mathrm{N} / 104^{\circ} 57^{\prime} 07^{\prime \prime} \mathrm{E}, \mathrm{h}=400-470 \mathrm{~m}, 6$ 15.VI.2014; $20^{7} 0^{7}, 5$ 우, Ha Tay Province, $\sim 45 \mathrm{~km} \mathrm{~W}$ of Hanoi, Ba
Vi National Park, $21^{\circ} 04^{\prime} \mathrm{N} / 105^{\circ} 21^{\prime} 38^{\prime \prime} \mathrm{E}, \mathrm{h}=1050-1100 \mathrm{~m}$, leaf litter, 18.VI.2014; $\sigma^{7}$, Nghe An Province, Que Phong District, Pu Hoat National Park, $19^{\circ} 45^{\prime} 19^{\prime \prime} \mathrm{N} / 104^{\circ} 47^{\prime} 47^{\prime \prime} \mathrm{E}, \mathrm{h}=840 \mathrm{~m}$, at light, 15-27.V.2019; $20^{7} 0^{7}$, Kon Tum Province, Kon Plong District, $14^{\circ} 44^{\prime} \mathrm{N} / 108^{\circ} 18^{\prime} \mathrm{E}$, env. ngoc Boc $1 \mathrm{Mt}, \mathrm{h}=1100-1200 \mathrm{~m}, 8-$ 23.IV.2015; $\sigma^{7}$, Gia Lai Province, $\sim 40 \mathrm{~km}$ ENE of Pleiku, $14^{\circ} 12^{\prime} 11^{\prime \prime} \mathrm{N} / 108^{\circ} 18^{\prime} 54^{\prime \prime}$, Kon Ka Kinh National Park, h=890 m, at light, 9-22.V.2016; 19, same data, except for $\sim 55 \mathrm{~km}$ ENE Pleiku, $14^{\circ} 17^{\prime} 45^{\prime \prime} \mathrm{N} / 108^{\circ} 26^{\prime} 57^{\prime \prime} \mathrm{E}, \mathrm{h}=600 \mathrm{~m}$, at light, 8-20.V.2017; $70^{7} \sigma^{7}, 2$ 우, Dak Lak Province, Chu Yang Sin Natn. Park, $12^{\circ} 23^{\prime} 48^{\prime \prime N} / 108^{\circ} 20^{\prime} 59^{\prime \prime} \mathrm{E}$, Krong Kmar river, upper flow, $\mathrm{h}=1000$ m, 30.III-14.IV.2012, at light; $20^{7} \sigma^{7}, 3$ 웅, Lam Dong Province, Bi Doup-Nui Ba Nature Reserve, env. Long Lanh, $12^{\circ} 10^{\prime} 44^{\prime \prime} \mathrm{N} /$ $108^{\circ} 40^{\prime} 44^{\prime \prime} \mathrm{E}, \mathrm{h}=1400-1600 \mathrm{~m}$, at light, 13.III-23.IV.2008; + , same data, except for $12^{\circ} 11^{\prime} \mathrm{N} / 108^{\circ} 42^{\prime} \mathrm{E}, \mathrm{h}=1500-1700 \mathrm{~m}, \sim 4 \mathrm{~km} \mathrm{SSE}$ of Hon Giao Mt, 29.IV.2009; ㅇ, 25 km NNW of Bao Loc, Loc Bao env., $\mathrm{h}=800 \mathrm{~m}, 11^{\circ} 44^{\prime} 18^{\prime \prime} \mathrm{N} / 107^{\circ} 42^{\prime} 08^{\prime \prime} \mathrm{E}$, at light, 5-20.IV.2013.

DIAGNOSIS. A larger species of the genus (Fig. 1), distinctive from similarly sized $M$. immarginatus and $M$. vandoesburgi in having pronotum generally longer, with its sides subsinuate and lateral margin slightly explanate and very smoothly and slightly reflexed in front of basal angles. Elytral apices truncate combined and blunt, discal setigerous pore $\mathrm{d} 2$ microscopic, invisible at low magnification; prosternum without or with a faint (sometimes distinct) median groove; pronotum and elytra iridescent and slightly sericeous.

REDESCRIPTION. Some additions only. BL 6.4-8.2 $\mathrm{mm}$. Dorsum black, pronotum and elytra along extreme lateral margins and often elytral apices vaguely reddish. Microsculpture superficial isodiametric before and slightly transverse behind the level of posterior margin of eyes, very superficial, consisting of narrow transverse meshes on pronotum and very dense transverse lines on elytra.

Head: frontal sulci slightly S-shaped. Labrum apically subsinuate to truncate.

Pronotum: sides subsinuate in front of basal angles, these with a minute to indistinct blunt tooth; lateral margin narrowly explanate and very slightly to indistinctly reflexed behind anterolateral seta or vaguely explanate and reflexed in basal third only, with a minute to indistinct impression just inside posterolateral seta. Basal margin slightly oblique outside basal sulci. Basal sulci nearly parallel, mostly reaching base, sometimes obliterate basally. Apical margin truncate or very gently concave, with apical angles rounded or slightly pointed and barely projecting, respectively. PW/PL 1.24-1.35, $\mathrm{PW} / \mathrm{HW}$ 1.48-1.65, PB/PA 1.28-1.40.

Elytra about half longer than wide, EL/EW 1.46-1.55, EW/PW 1.30-1.40. Interval 3 behind middle with a vestigial, microscopic, 'setigerous' pore d2 near stria 2.

Prosternum without, sometimes with a distinct, median groove; prosternal process not or vaguely bordered at apex.

Aedeagus (Figs 4-5, 11, 15-16): median lobe geniculate, smoothly curved, longitudinal median carina conspicuous, with apical half gradually narrowed apicad in dorsal/ventral view; apex short, thick and slightly curved ventrad in lateral view.

Abdominal urites VIII and IX in female as in Figs 25-26, 34

GEOGRAPHIC DISTRIBUTION. Throughout Vietnam, from Phu Tho and Ha Tay provinces in the north to Lam Dong Province in the south. So wide species range may suggest that the species occurs also in the adjacent parts of Laos.

HABITATS AND HABITS. As indicated above for the genus.

COMMENTS. The northernmost populations of the species (Phu Tho and Ha Tay provinces) are slightly different from southernmost ones (Lam Dong and Dak Lak provinces) in some characters, including body proportions (Table). In the north, the adults have the eyes barely smaller, with a bit more obtuse angle between gena and neck, and the ratio PW/ 
Table. Body ratios in local populations of M. hermanni. Таблица. Индексы пропорций тела в локальных популяциях M. hermanni.

\begin{tabular}{l|c|c|c|c|c|c|c|c|c|c|c|c|c}
\hline \multicolumn{1}{c|}{ locality } & $\mathbf{n}$ & $\mathbf{P W} / \mathbf{H W}$ & $\mathbf{m}$ & $\mathbf{P W} / \mathbf{P L}$ & $\mathbf{m}$ & $\mathbf{P B} / \mathbf{P A}$ & $\mathbf{m}$ & $\mathbf{E W} / \mathbf{P W}$ & $\mathbf{m}$ & $\mathbf{E L} / \mathbf{E W}$ & $\mathbf{m}$ & $\mathbf{E L} / \mathbf{P L}$ & $\mathbf{m}$ \\
\hline $\mathrm{BD}+\mathrm{CYS}$ & $5+5$ & $1.48-1.53$ & $\mathbf{1 . 5 1}$ & $1.24-1.29$ & $\mathbf{1 . 2 7}$ & $1.30-1.40$ & $\mathbf{1 . 3 6}$ & $1.30-1.39$ & $\mathbf{1 . 3 5}$ & $1.50-1.55$ & $\mathbf{1 . 5 3}$ & $2.53-2.70$ & $\mathbf{2 . 6 0}$ \\
$\mathrm{KP}$ & 1 & 1.54 & 1.54 & 1.31 & 1.31 & 1.39 & 1.39 & 1.38 & 1.38 & 1.50 & 1.50 & 2.72 & 2.72 \\
$\mathrm{PH}$ & 1 & 1.50 & 1.50 & 1.29 & 1.29 & 1.38 & 1.38 & 1.40 & 1.40 & 1.51 & 1.51 & 2.72 & 2.72 \\
$\mathrm{BV}+\mathrm{XS}$ & $2+5$ & $1.57-1.65$ & $\mathbf{1 . 6 2}$ & $1.28-1.35$ & $\mathbf{1 . 3 1}$ & $1.28-1.37$ & $\mathbf{1 . 3 2}$ & $1.30-1.36$ & $\mathbf{1 . 3 3}$ & $1.46-1.50$ & $\mathbf{1 . 4 8}$ & $2.48-2.62$ & $\mathbf{2 . 5 6}$
\end{tabular}

BD — Bi Doup-Nui Ba Nature Reserve; BV — Ba Vi National Park; KP — Kon Plong District; PH — Pu Hoat National Park; XS — Xuan Son National Park; $m$ - mean.

BD - Bi Doup-Nui Ba Nature Reserve; BV — Ba Vi National Park; KP — Kon Plong District; PH — Pu Hoat National Park; XS — Xuan Son National Park; $\mathrm{m}$ - среднее арифметическое.

HW is greater accordingly. Besides, the pronotum is barely wider, with the apical margin very gently sinuate ( $v s$. truncate), the apical angles a bit sharper, barely more prominent and more distant from the neck; and the elytra are barely shorter in general.

\section{Metabacetus laotinus Straneo, 1938}

Figs 2, 6-7, 12, 17-18.

Straneo, 1938a: 152-153 (Xieng Khouang env., Laos); Will, Park, 2008: 194.

MATERIAL. Two specimens (SIEE): Vietnam: $\sigma^{7}$, Lam Dong Province, Bi Doup-Nui Ba Nature Reserve, env. Long Lanh, $12^{\circ} 10^{\prime} 44^{\prime \prime} \mathrm{N} / 108^{\circ} 40^{\prime} 44^{\prime \prime} \mathrm{E}, \mathrm{h}=1400-1600 \mathrm{~m}$, at light, 28.IV10.V.2009 (D. Fedorenko); + , Cao Bang Province, $40 \mathrm{~km} \mathrm{~W}$ of Cao Bang, Phia Oac Mt., eastern slope, $h=1600-1800 \mathrm{~m}, 22^{\circ} 36^{\prime} 27^{\prime \prime} \mathrm{N} /$ $105^{\circ} 52^{\prime} 0^{\prime \prime} \mathrm{E}, 22 . \mathrm{V}-6 . \mathrm{VI} .2018$ (A. Abramov).

DIAGNOSIS. As for the previous species, except that pronotal sides are straight or subconvex in front of basal angles, and lateral margin rather widely explanate and reflexed in basal half; elytral discal pore d2 small yet traceable.

REDESCRIPTION. As for the previous species except as follows: Body (Fig. 2) barely smaller, BL 6.1-7.1 mm. Pronotum more widely reddish along sides. Pronotal and elytral microsculpture consisting of very dense transverse lines, indistinct on pronotal disc and almost so on neck in male.

Head barely smaller, PW/HW 1.57-1.62, frontal sulci deep and divergent to slightly S-shaped behind. Labrum apically subsinuate.

Pronotum barely narrower, PW/PL 1.23-1.28, with narrow base, PB/PA 1.17-1.26. Sides straight in basal half, explanate lateral margin moderately wide and conspicuously reflexed behind anterolateral seta. Basal margin distinctly oblique outside basal sulci; these reaching base, slightly converging apicad. Apical bead obliterated in middle fifth.

Elytra: EL/EW 1.49-1.51, EW/PW 1.35-1.37. Intervals subconvex in $\sigma^{7}$, convex in + ; 'setigerous' pore $\mathrm{d} 2$ minute yet traceable, adjoining or near stria 2.

Prosternum with a vague median groove, prosternal process not apically bordered.

Aedeagus (Figs 6-7, 12, 17-18): median lobe in lateral view more sharply curved, with longitudinal median carina rather narrow and apex very thin; in ventral view fusiform, much broader at middle than at extremities.

GEOGRAPHIC DISTRIBUTION. Laos and Vietnam.

HABITATS AND HABITS. As for the genus.

\section{Metabacetus perakianus Straneo, 1938 Figs 3, 8-14.}

Straneo, 1938a: 152, 157 (Perak); Will, Park, 2008: 194.

MATERIAL. Two specimens, $O^{7}, 3$ 우, (SIEE): Vietnam: Nghe An Province, Que Phong District, Pu Hoat National Park, $19^{\circ} 45^{\prime} 19^{\prime \prime} \mathrm{N} / 104^{\circ} 47^{\prime} 47^{\prime \prime} \mathrm{E}, \mathrm{h}=840 \mathrm{~m}$, at light, 15-27.V.2019 (D. Fedorenko).

DIAGNOSIS. A smaller species within the genus (Fig. 3 ), pronotal sides rounded, lateral margin explanate and rather smoothly and slightly reflexed in basal half; elytral apices truncate combined and blunt, discal setigerous pore $\mathrm{d} 2$ minute yet traceable; prosternum without or with a distinct median groove anteriorly adjoining a deep pit; pronotum and elytra iridescent.

REDESCRIPTION. Some additions only. BL 5.4-6.1 $\mathrm{mm}$. Dorsum black and slightly iridescent, extreme lateral margins of both pronotum and elytra slightly reddish. Microsculpture superficial on head, isodiametric before, slightly transverse behind, very superficial on pronotum and elytra, consisting of narrow transverse meshes or very dense transverse lines, respectively.

Head: frontal sulci reaching the level of anterior supraocular seta, S-shaped, parallel behind clypeus, diverging behind, and again parallel just posteriorly. Labrum subsinuate at apical margin.

Pronotum rounded on sides, with lateral margin rather widely explanate and rather smoothly reflexed in basal half. Base and apex truncate, the former distinctly oblique outside basal sulci; these reaching base and slightly converging apicad. PW/PL 1.33-1.36 (1.35), PW/HW 1.53-1.62 (1.56), PB/PA 1.37-1.47 (1.41).

Elytra short and wide, EL/EW 1.42-1.45 (1.44), EW/PW 1.33-1.40 (1.47). Interval 3 behind middle with a minute yet distinct 'setigerous' pore $\mathrm{d} 2$ near stria 2 .

Prosternal process not apically bordered.

Aedeagus (Figs 8-14): median lobe as for M. hermanni, except for more sharply curved in lateral view and less narrowed apicad in ventral view.

GEOGRAPHIC DISTRIBUTION. Known from the only locality in Vietnam, in addition to the type locality, Perak, the Malay Peninsula.

HABITATS AND HABITS. The specimens listed above have been collected at light, at the edge of a montane, monsoon, broad-leaved forest.

COMMENTS. A very characteristic feature of the species, prosternum with a small and deep median pit, has not been mentioned in the original description. The specimens examined otherwise match the description well. 

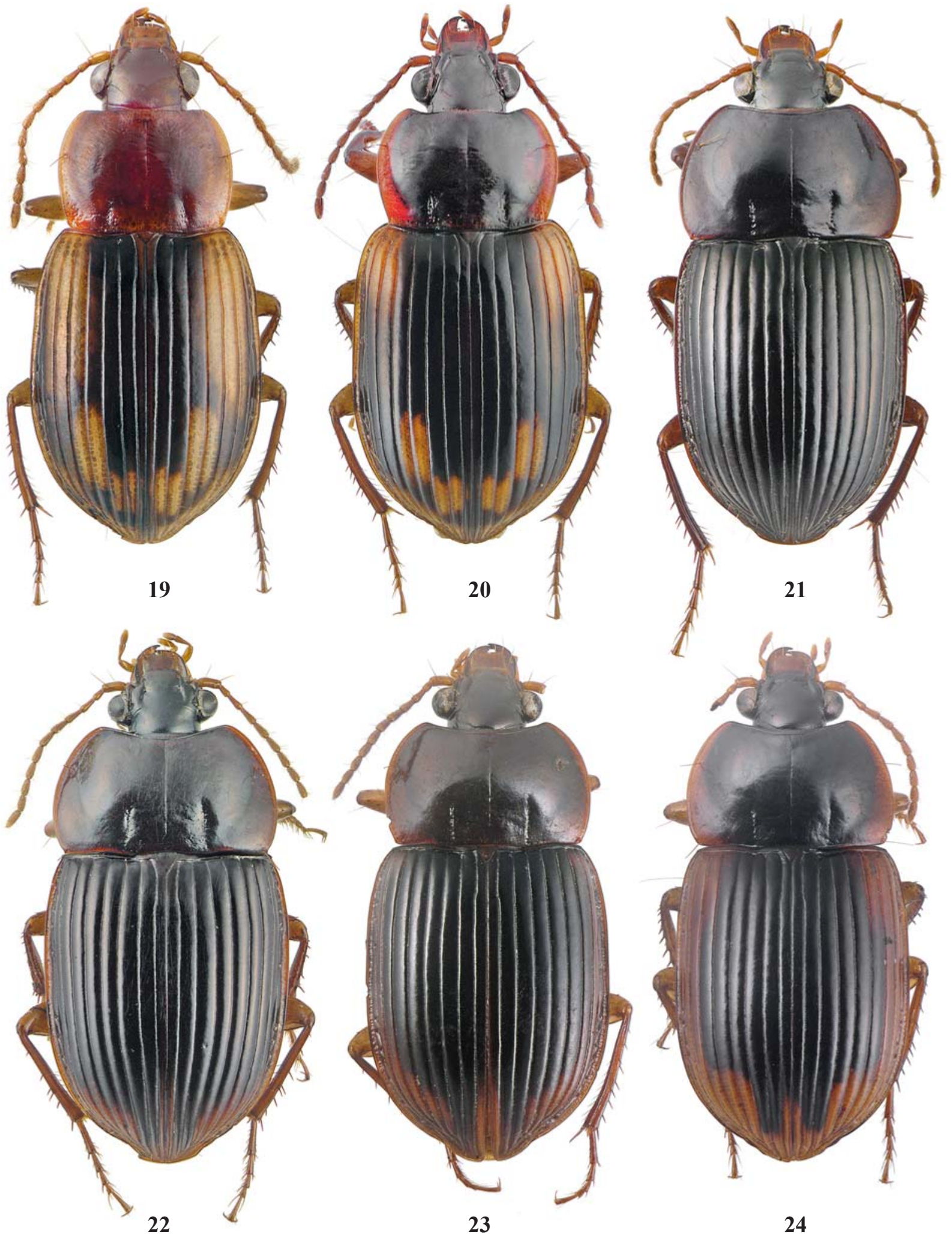

Figs 19-24. Dorsal habitus: 19 - Aristopus picturatus, 9 from Anuradhapura env., Sri Lanka; $20-$ A. humeratus sp.n., paratype $\odot^{7}$ from env. Pai, Thailand; 21 - Cosmodiscus platynotus,, from the Bi Doup — Nui Ba Nature Reserve; 22 - C. rufoapicalis sp.n., holotype; 23 - C. rufolimbatus, holotype; $24-$ C. louwerensi, paratype.

Рис. 19-24. Габитус дорзально: 19 - Aristopus picturatus, + чз окр. Анурадхапура, Шри Ланка; 20 - A. humeratus sp.n., паратип $\mathrm{O}^{7}$ из окр. Паи, Таиланд; $21-$ Cosmodiscus platynotus, + из запов. Бидуп-Нуйба; $22-$ C. rufoapicalis sp.n., голотип; $23-C$. rufolimbatus, голотип; $24-$ C. louwerensi, паратип. 


\section{Aristopus LaFerté-Sénectère, 1853}

LaFerté-Sénectère, 1853: 373; Straneo, 1982: 338; 1983: 313; Will, 2020a: 165. — Celioschesis Tschitschérine, 1898: 93 (type species: Distrigus bipustulatus Brullé, 1834, designated by Jeannel, 1948); Péringuey, 1926: 628; Straneo, 1940: 211; Jeannel, 1948: 442.

Type species: Aristopus trimaculatus LaFerté-Sénectère (by monotypy).

DIAGNOSIS. As for Metabacetus, except that the body is robust, reminiscent of Amara Bonelli, 1810, subgenus Celia C. Zimmermann, 1832, dark brown to black, mostly with pale elytral pattern, mandibles shorter and more incurved, eyes nearly hemispherical, labial pits missing, tibiae, especially mesotibia, more strongly armed with spiniform setae, metatibia with 2-4 spiniform setae (vs. glabrous) along outer margin, basal bead distinct outside basal sulci ( $v s$. totally obliterate), elytral discal pore $\mathrm{d} 2$ present in most species. Abdominal sternite VII with medial setae distant far from apical margin in both sexes and thence arranged into a transverse row in female. - See also 'Comments' below.

REDESCRIPTION. Body (Figs 19-20) convex, black or dark brown, often iridescent due to the presence of a very superficial microsculpture consisting of very transverse meshes or very dense transverse lines; body appendages, more or less wide pronotal margins, reflexed lateral margins of elytra, and maculate elytral pattern red or reddish-yellow.

Dorsal setation complete, except that elytral discal setae are reduced to $\mathrm{d} 2$ or (three species from Indochina) totally, combined with parascutellar seta lost in the latter case.

Head medium-sized, without neck constriction behind eyes; these large, convex, almost hemispherical, nearly reaching maxillary grooves beneath; genae short, subtransverse, meeting neck at obtuse angle (vs. nearly right in Cosmodiscus), anteroventrally without antennal grooves; frontal sulci mostly short, deep and divergent. Mandibles normal in shape, i.e., moderately long, distinctly incurved in apical half, with dorsolateral margin rounded at least medially. Apical maxillary and labial palpomere fusiform, penultimate labial palpomere bisetose. Mentum with a distinct median tooth varying between species in shape.

Pronotum quadrate to obtrapezoidal; sides rounded, entirely beaded; disc convex; lateral margin mostly explanate and reflexed, becoming increasingly wide toward base. Base truncate or laterally oblique, beaded outside basal sulci; basal angles obtuse, not or minutely toothed. Apex truncate or subsinuate, with apical angles slightly projecting; apical bead entire to totally obliterate. Basal sulci deep, parallel or converging apicad, running on about basal third. Basal sulci at bottom and sides more or less distinctly punctate.

Elytra rather wide, with humeri and preapical sinuation distinct, sides rounded to subparallel. Basal ridge entire, humeral angle obtuse. Striae entire, deep, impunctate, stria 7 separately reaching apex, stria 8 starting from basal ridge or humerus. Intervals 8 and 9 subequally wide except basally, USS consisting of 14 US, with patterns 6-1-7, 6-1-7 and 77 being observed due to intermediate seta varying between specimens of one species in position. Parascutellar seta at base of stria 2. Stria 7 with two distinct setae at apex.

Legs rather strong, protibia apically more or less dilated, with three lateroapical spines, these equidistant inter se or apical two proximate. Mesotibia with strong spiniform setae, 4-5 anterolateral and one posterolateral near distal anterolateral seta; inner setal brush consists of 8-12 setae becoming increasingly short and curved basad, with distal seta being longest and more or less separated from the others. Metatibia with 2-4 strong outer setae. Meso- and metatarsomeres 1-3 with more or less distinct lateral setae just above ventral setae; meso- and metatarsomere 1 or metatarsomeres 1 and 2 with outer (anterior) dorsolateral sulcus. Tarsomere 5 with dorsal (dorsolateral) seta preapical in position; tarsomeres 1 and 2 with DAS subequally developed in all tarsi; tarsomere 4 with ventro-apical setae simple (not lamellate). Protarsomeres 1-3 dilated and biserially squamose in male, those 1 and 2 toothed at latero-apical angles in female.

Aedeagus (Figs 38-41, 50-51, 56-59): median lobe arcuate, with a longitudinal ventromedial carina in the curve and apex slightly upturned in lateral view. Internal sac with a few, more or less distinct, sclerotized folds.

Abdominal urite VIII in female as in Figs 27-36. Female genitalia and reproductive tract (Figs 31, 36-37): Urite IX with ventral membrane setulose, laterotergite apically rounded, setulose; gonosubcoxite glabrous (A. bipustulatus, $A$. picturatus) or with three small and dense lateroapical setae (A. humeratus sp.n.), gonocoxite triangular, with double preapical nematiform seta, a very strong ventral ensiform seta and no dorsal setae, sometimes (single specimen of $A$. humeratus sp.n.) with 2-3 ventral ensiform setae (Fig. 36); bursa copulatrix membranous, spermatheca long convoluted.

GEOGRAPHIC DISTRIBUTION. Widespread in the Paleotropical realm, including Afrotropical, Madagascan and Oriental (India to Indochina) regions.

HABITATS AND HABITS. No data, except that most specimens of two species reviewed here have been collected at light.

COMMENTS. According to Straneo [1983], the genus includes 20 Afrotropical and three Madagascan species.

In interpreting this genus, authors allowed some faults to occur. Firstly, Andrewes [1920] described a new species within the formerly monobasic Australian genus Cosmodiscus, while making no comparison between it and any representative of similar African (and Madagascan) genera Aristopus or Celioschesis. He did not accidentally described the elytral setation for Cosmodiscus and found no grounds to differentiate between Cosmodiscus platynotus and the other two species reviewed. Just after, Andrewes [1921] rectified his omission by stressing the point that $C$. picturatus Andrewes, 1920 had the median elytral discal seta (d2) and the congeners had no discal setae at all, while passing a side remark on an undescribed species of Cosmodiscus from South Africa. Later, the names Aristopus LaFerté-Sénectère, 1853 and Celioschesis Tschitschérine, 1898 were recognized as congeneric [Straneo, 1982], and Cosmodiscus Sloane, 1907 has recently been mentioned as the next probable synonym [Will, 2020a].

In spite of the Andrewes' note about the seta $\mathrm{d} 2$ [Andrewes, 1921] Straneo [1940] only distinguished between Cosmodiscus and Celioschesis by the elytra without discal setae or with d2, respectively. He [Straneo, 1940] otherwise recognized the two genera as close relatives defined by the 'normal' aedeagus (vs. inversed in Drimostomatina, as Caelostomini), combined with the elytral parascutellar striole missing, parascutellar seta at base of stria 2, and USS being continuous. Then Straneo [1951] erected the genus Celioinkosa for Celioschesis kivuana Burgeon, 1935, based chiefly on its distinctive mandibles, dorsally depressed and obliquely striated, combined with the body Amara-like following the subequally wide pronotal and elytral bases, and also the pronotal lateral margin widely explanate and reflexed, elytral d2 missing, the apical labial palpomere fusiform, and the prosternal process not beaded. Later [Straneo, 1995], he reported that this character combination defined also the genera Inkosa Péringuey, 1926 and Oodinkosa Straneo, 1951, and discriminated between the three genera by the apical labial palpomere peculiar in shape, subtriangular in Oodinko- 
$s a$, subparallel-sided in Inkosa, and oval in Celioinkosa, in couple with slight differences between the aedeagi of Inkosa and Oodinkosa on one hand, and that of Celioinkosa, on the other. Surprisingly, this author never compared all these taxa or at least $C$. kivuana with Cosmodiscus platynotus or $C$. louwerensi Straneo, 1940, even though no generic differences as above could be found between these three.
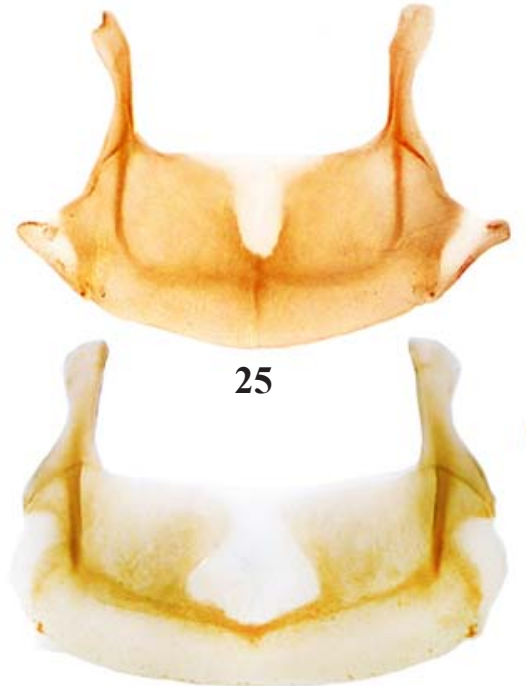

27

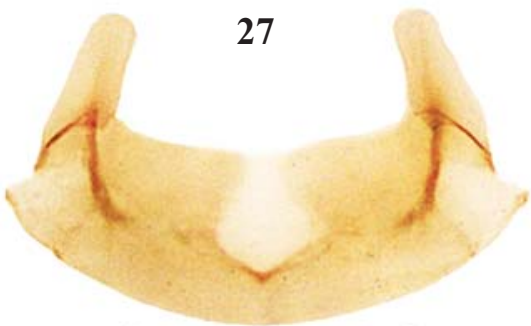

29

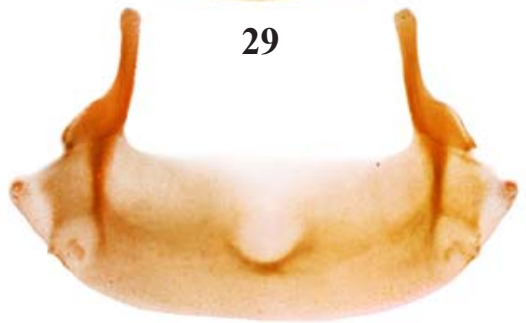

32

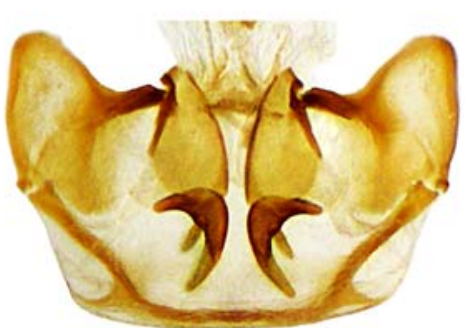

35

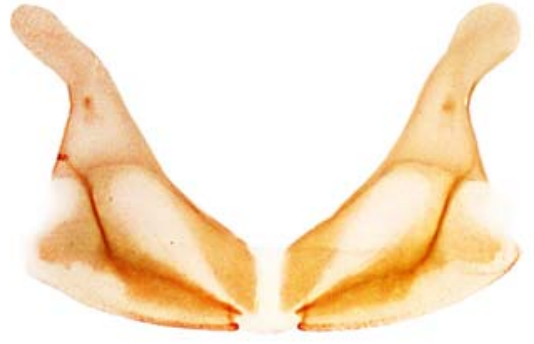

26

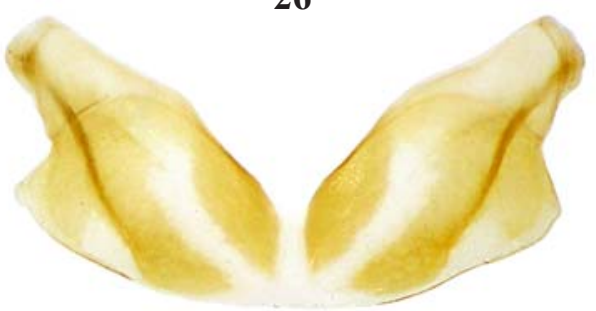

28

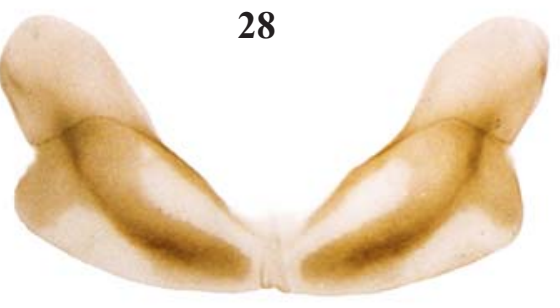

30

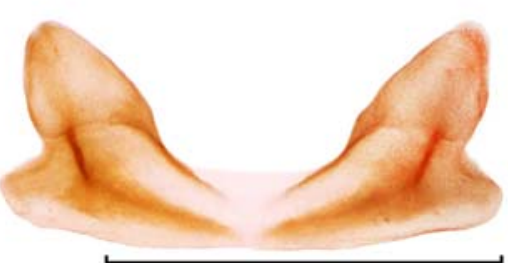

33

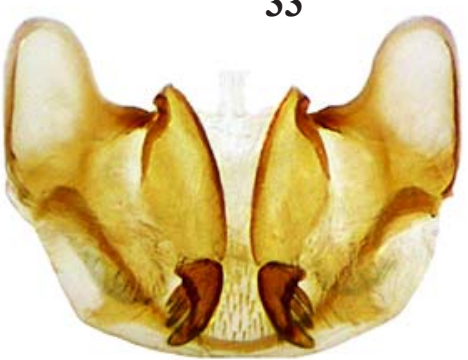

36
The characters discussed were also used in the key for identification of the Central African abacetine genera [Straneo, 1982], which did not cover Afrotropical or Madagascan genera distributed beyond this region: Inkosa, Cyrtomoscelis Chaudoir, 1874, and Pioprosopus Tschitschérine, 1899. This latter [Tschitschérine, 1899; 1902] seems to be very similar to Inkosa, Oodinkosa, and especially to Celioinkosa, except 
only that it has short metepisternum and the neck constriction which is more or less traceable behind the eyes.

My comparison between Celioinkosa mirei Straneo, 1995 (Fig. 70), three species of Aristopus, one African (A. basilewskyi Straneo, 1948) and two Madagascan (A. bipustulatus Brullé, 1834, the type species of Celioschesis, and A. mocquerysi Jeannel, 1948), and most species of 'Cosmodiscus' (Figs 19-24, 68-69) has revealed, firstly, that some significant characters vary between these species considerably, so that both the elytral parascutellar seta and $\mathrm{d} 2$ may be present or not. Secondly, the combination of the following five characters $\left(n^{0} / n^{1}\right.$, plesiotypic/apotypic state; $n^{\mathrm{a}} / \mathrm{n}^{\mathrm{b}}$, unordered) serve good for arranging all the species into two groups (for additional differences see the key below):

1) Mandibles normal in shape, elongated, slightly incurved, with dorsal side slightly flattened inside a more or less rounded dorsolateral edge $\left(1^{0}\right)$. - Vs. mandibles as described for Celioinkosa, i.e., shorter, wider and more incurved, dorsally depressed just inside a carinate dorsolateral edge $\left(1^{1}\right)$;

2) Abdominal sternite IV either with $\left(2^{0}\right)$ or without $\left(2^{1}\right)$ paramedian obligatory setae;

3) Pronotal apical bead either entire $\left(3^{0}\right)$ or obliterate medially to totally $\left(3^{1}\right)$;

4) USS posterior group contains either seven (4a) or eight $\left(4^{b}\right)$ setae, respectively;

5) Pronotal basal bead either laterally distinct $\left(5^{\circ}\right)$ or totally obliterate $\left(5^{1}\right)$.

The first group includes species of Aristopus, 'Cosmodiscus' picturatus and an undescribed species; all of them are defined by the combination $1^{0} 2^{0} 3^{1} 4^{\mathrm{a}} 5^{0}$ and have smaller eyes. Based on the evidence the two species of 'Cosmodiscus' are here either transferred to (C. picturatus) or described below within Aristopus, and the fact that the parascutellar seta and seta $\mathrm{d} 2$ are absent from the elytra of $A$. humeratus sp.n. restricts character combination to discriminate Aristopus from Cosmodiscus or other genera. Because A. humeratus sp.n. is very similar to Drimostoma kaszabi Jedlička, 1954, in many characters, including colour pattern of the elytra, parascutellar and discal setae missing, and the pronotum with apical bead interrupted in the middle, the latter species is here provisionally placed within Aristopus. Just the same is true of C. latus Andrewes, 1947, even though Andrewes [1947] said nothing about parascutellar seta in the description while noted great similarity between $C$. latus and $C$. umeralis Andrewes, 1937, a true member of Cosmodiscus.

The remaining species of Cosmodiscus share character combination $1^{1} 2^{1} 3^{0} 4^{\mathrm{b}} 5^{1}$ (or at least $1^{1} 3^{0}$ because the other characters remain not examined across Inkosa, Oodinkosa, Celioinkosa and Aristopus) which invites synonymy Cosmodiscus Sloane, 1907 = Celioinkosa Straneo, 1951, syn.n., whether Cosmodiscus and Aristopus are recognized as congeners elsewhere or not.

There are two defects in the scheme proposed: (1) some African species of Aristopus [Straneo, 1983] have entire apical bead of the pronotum and (2) Oodinkosa leleupi Straneo, 1960 has the median lobe of aedeagus [Straneo, 1995] more similar to that of Cosmodiscus. Aedeagi otherwise are more or less distinctive in the genera compared. Specifically, the median lobe in lateral view has the apex straight to slightly upturned, combined with ventral margin concave, in Aristopus, Inkosa and Oodinkosa, but curved ventrad in Cosmodiscus, ventral margin being concave in eastern (Cosmodiscus s.str.) or bisinuate in western (= Celioinkosa) species (Figs 42-49).

It has also been found that the mentum and the submentum vary between the examined species of Aristopus consid- erably in shape, which may reflect species-specific differences. In particular, the submentum is deeply transversely impressed at its base, with the gular sutures impressed in form of small deep pits, in A. picturatus and A. humeratus sp.n. and slightly less so in $A$. bipustulatus. The mentum tooth is either large and apically rounded (A. humeratus sp.n.) or smaller, apically truncate and subsinuate (A. picturatus), or still shorter, apically truncate and wide (A. bipustulatus), or large, very convex along middle, apically rounded yet subtruncate, i.e., with latero-apical angles somewhat traceable (A. mocquerysi). This latter species is distinctive also in having the ridge (that separates between the mentum and its tooth and then laterally extends into epilobes) submarginal, bead-like ( $v s$. transverse in the other three species), combined with the submentum not transversely impressed.

\section{Aristopus humeratus Fedorenko, sp.n.}

Figs 20, 29-30, 36, 38-39, 50, 56-57.

MATERIAL. Holotype $\sigma^{\prime}$ (ZMMU) labelled: 'S[outh] Vietnam, N[orthern part of] Dongnai Pr[ovince]./ Nam Cat Tien Nat[ional]. Park/ Exped[ition of the Joint]. Russ[ian].-Vietnamese/ Tropical Centre/ at light HQL-450 10./ leg. D.Fedorenko .VI.2005'. Paratypes (SIEE, ZISP): $30^{7} 0^{7}, 7$ 오, same data, but various dates, including 2-3. and 10-11.VI.2005; 2 오, Vietnam, Binh Phuoc Prov., Bu Gia Map Natn. Park, $12^{\circ} 11^{\prime} 37^{\prime \prime N} / 107^{\circ} 12^{\prime} 21^{\prime \prime} \mathrm{E}, \mathrm{h}=350$ $540 \mathrm{~m}$, at light, 17. or 22-22.IV.2009, leg.D.Fedorenko'; $2 \mathrm{O}^{7} \sigma^{7}$, 'Vietnam, Lam Dong Province, $35 \mathrm{~km}$ NNW of Bao Loc, Loc Bao env., $h=650 \mathrm{~m}, 11^{\circ} 50^{\prime} 12^{\prime \prime} \mathrm{N} / 107^{\circ} 38^{\prime} 25^{\prime \prime} \mathrm{E}$, at light, 17-22.IV.2012, D.Fedorenko leg.'; + ' 'N-Vietnam, Ninh Binh Prov., $7.5 \mathrm{~km} \mathrm{SSW}$ of Nho Quan, Dong Tam vill., $20^{\circ} 15^{\prime} 08^{\prime \prime} \mathrm{N} / 105^{\circ} 44^{\prime} 09^{\prime \prime} \mathrm{E}, \mathrm{h} \sim 100 \mathrm{~m}$, at light, 1-5.V.2019, A. Prosvirov leg.'; $\sigma^{\top}, 2$ $9+$, 'N Thailand, Mae Hong Son Prov., env. Pai, $19^{\circ} 21^{\prime} 42^{\prime \prime} \mathrm{N} / 98^{\circ} 27^{\prime} 46^{\prime \prime} \mathrm{E}-19^{\circ} 22^{\prime} \mathrm{N} /$ 98 30'29' E, h 600 m, 27.IV-9.V.2013, leg. I.Melnik'.

Additional material: 9 (ZSM), Thailand, Chiang Mai, Doi Intha Non Natn. Park, $\mathrm{h}=332 \mathrm{~m}, 18.50^{\circ} \mathrm{N} 98.67^{\circ} \mathrm{E}, 21.08 .2012$ (V.K. Zinchenko); + (ZISP), Nepal, Loc.no.26, Nuwakot, Ranipauwa env., $27^{\circ} 47.24^{\prime} \mathrm{N}, 8^{\circ} 16.17^{\prime} \mathrm{E}, 1730 \mathrm{~m}, 6 . \mathrm{V} .2000$, Expedition A.Konstantinov, S.Lingafelter \& M.Volkovitsh.

DIAGNOSIS. The Oriental species of Aristopus with maculate elytra, distinguishable from the western species $A$. picturatus (Andrewes, 1920), comb.n., by having no elytral parascutellar or discal setae, and humeral maculae being smaller. The presence of the humeral macula differentiates the new species from both $A$. latus (Andrewes, 1947), and $A$. kaszabi (Jedlička, 1954), and very long frontal sulci distinguish it from the latter three. Totally obliterate apical bead of pronotum and unisetose metafemur are additional unique features.

DESCRIPTION. BL 6-8 mm. Body (Fig. 20) shiny black, pronotum dark brown black, slightly reddish along both base and apex; anterior half of clypeus, labrum, explanate lateral margin of pronotum, mouthparts, legs, antennae, elytral epipleura and pattern, as well as abdominal sternite VII in apical half, red or reddish yellow. Elytral pale pattern includes reflexed lateral margin (outside stria 9), apex, humeral spot and two quadrate preapical spots. Humeral spot spanning intervals 6-9 in basal 1/4-1/5; anterior preapical spot on intervals 4 and 5 (sometimes only on 4), posterior one slightly smaller, running on interval 2 and 3, and touching the anterior spot; pale apex shorter than to as long as posterior preapical spot, laterally almost reaching the level of apical margin of anterior preapical spot. Underside reddish brown to brown black.

Microsculpture consisting of extremely fine and very dense transverse lines along pronotal base and on elytra in female, mostly absent or almost so in male; dorsal iridescence accordingly varying between very distinct to imperceptible.

Head with large hemispherical eyes. Frontal sulci very long, deep and divergent anteriorly, less deep and slightly 
S-shaped at anterior supra-ocular seta, moderately deep behind, reaching and diverging toward posterior supraocular seta. Labrum apically subsinuate to truncate. Antennae barely or indistinctly longer in male than in female, almost reaching or surpassing pronotal base by apical half of antennomere 11 .

Pronotum subquadrate, transverse, half wider than long, PW/PL 1.49-1.54 (1.52, n=7), more than two thirds wider

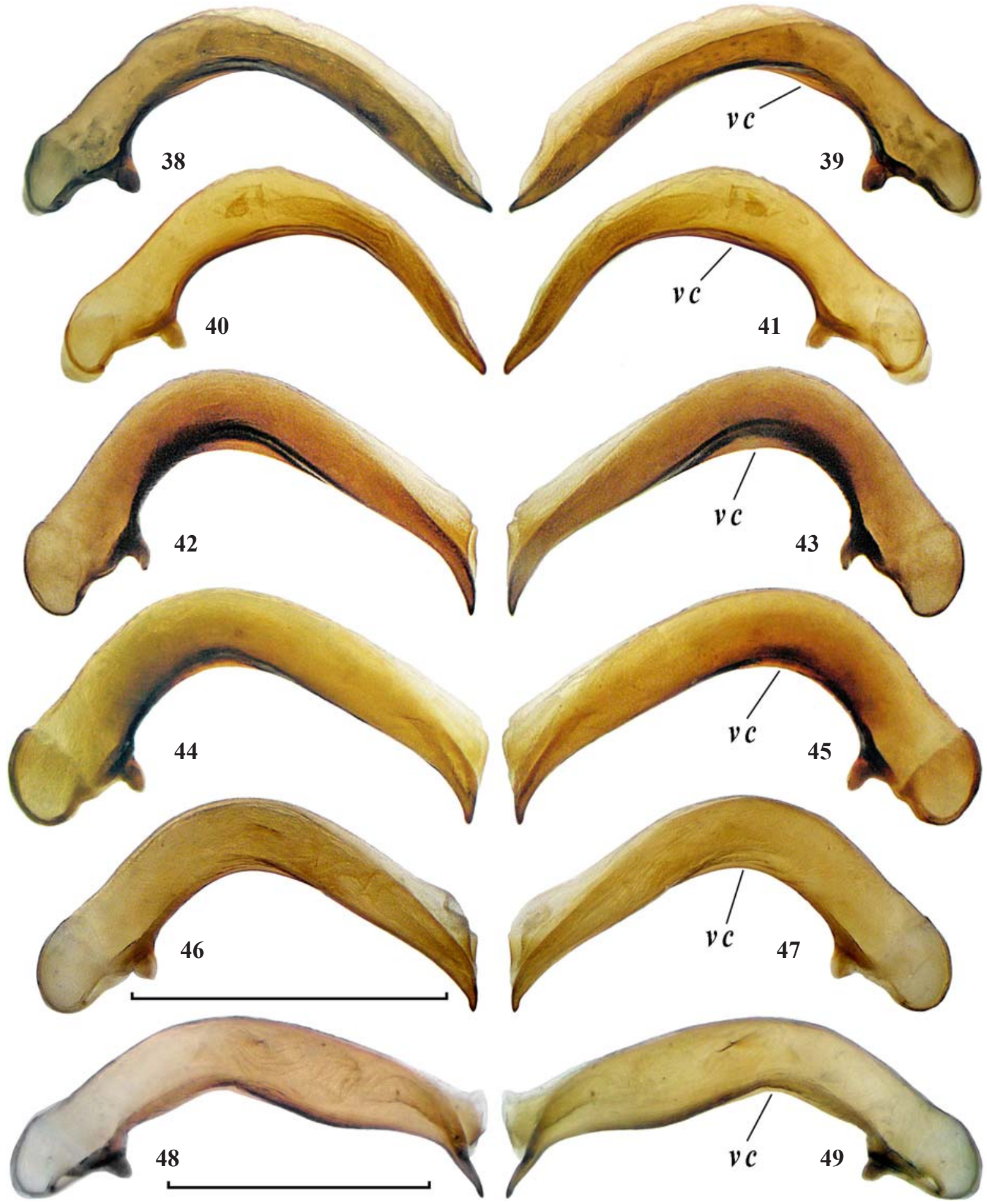

Figs 38-49. Median lobe of aedeagus: 38-39 — Aristopus humeratus sp.n., paratype $\mathrm{O}^{7}$ from env. Pai, Thailand; 40-41 — A. picturatus, $0^{7}$ from Vilpattu, Sri Lanka; 42-43 - Cosmodiscus platynotus; 44-45 - C. rufoapicalis sp.n., holotype; 46-47 - C. louwerensi, paratype; 48-49-C. mirei; 38, 40, 42, 44, 46, 48 - left aspect; 39, 41, 43, 45, 47, 49 - right aspect; $\boldsymbol{v} \boldsymbol{c}$ - ventral longitudinal carina. Scale bars: $1 \mathrm{~mm}$.

Рис. 38-49. Средняя доля эдеагуса: 38-39-Aristopus humeratus sp.n., паратип О7 из окр. Паи, Таиланд; 40-41 - A. picturatus, О7 из Вильпатту, Шри Ланка; 42-43 - Cosmodiscus platynotus; 44-45 - C. rufoapicalis sp.n., голотип; 46-47 - C. louwerensi, паратип; 48-49-C. mirei; 38, 40, 42, 44, 46, 48 - слева; 39, 41, 43, 45, 47, 49 - справа; vc - продольный вентральный киль. Масштаб: 1 мм. 
than head, PW/HW 1.66-1.71 (1.70). Sides rounded, not or minutely sinuate just in front of obtuse and apically blunt basal angles. Explanate lateral margin slightly yet abruptly reflexed, becoming increasingly wide toward base, very wide basally; lateral bead fine and entire. Base a third wider than apex, PB/PA 1.28-1.40 (1.33), truncate medially, slightly oblique and more or less distinctly, sometimes vaguely, beaded outside basal sulci. These deep, parallel, running on basal third, obliterate basally. Apical margin truncate to slightly convex at middle; apical angles projecting, right to very slightly acute, with apices blunt; apical bead totally obliterate. Median line very fine, mostly obliterate basally and apically, to almost imperceptible. Disc otherwise convex and smooth, basal sulci finely and confluently punctate at bottom, sometimes with a few punctures at sides, explanate lateral margin finely and sparsely to vaguely punctate, more densely and more distinctly along lateral and basal beads.

Elytra about a third longer than wide, EL/EW 1.36-1.39 (1.37), and a fourth wider than pronotum, EW/PW 1.26-1.31 (1.27), almost parallel-sided, broadest behind middle, slightly yet distinctly sinuate before apex; apices blunt and almost truncate combined; sides varying between very slightly rounded and barely concave. Humeri distinct, each in posteromedial view without or with a minute pointed tooth; basal ridges slightly concave combined, humeral angle very obtuse and somewhat rounded. Striae entire, deep, sulcate, impunctate, crenulate or not, much deeper toward apex, with inner two often shallower on disc. Intervals flat to subconvex, convex or very so in apical $1 / 3-1 / 4$. Neither parascutellar nor discal setae present. Stria 7 with two apical setae. USS (see 'Comments' below) with US10 large, adjoining stria 8 and slightly separated from stria 9.

Underside: Prosternum without median groove, prosternal process not apically beaded. Mesepisterna in anterior half, metepisterna, abdomen except along middle, finely and densely punctate; sometimes propleura close to anterior margin of procoxae and extreme sides of metaventrite with a few similar punctures. Abdominal sternite VII bisetose in male, quadrisetose in female.

Legs. Protibia apically dilated, with three latero-apical spines. Mesotibia with 4-5 spiniform anterolateral setae, inner setal brush consisting of $8+1$ or $9+1$ setae; metatibia with $2-4$ spiniform setae at outer margin. Metafemur with the only anterolateral seta, distal. Basal three protarsomeres dilated and biserially squamose in male or toothed at latero-apical angles in female, teeth being very small on protarsomere 3 .

Aedeagus (Figs 38-39, 50, 56-57): Internal sac with three sclerotized folds in apical half.

Abdominal urites VIII and IX in female as in Figs 29-30, 36.

NAME. Refers to the elytral humeral macula as a characteristic feature of this species.

GEOGRAPHIC DISTRIBUTION. Nepal, Thailand, Vietnam, and probably also Laos. In Vietnam, the species is more frequent in the south than in the north.

HABITATS AND HABITS. Virtually all the specimens examined have been taken at light at the edges of broadleaved monsoon forests.

COMMENTS. The new species is very similar to A. latus from Myanmar and A. kaszabi from Taiwan, each described based on a single female specimen within either Cosmodiscus or Caelostomus Macleay, 1825 (as Drimostoma Dejean, 1831), respectively. Those two are distinctive in only having short frontal sulci, the elytra without pale humeral spot, and the pronotal apical bead interrupted medially. This high similarity between the three taxa makes subspecies status of A. humeratus sp.n. not improbable, which problem is hardly soluble until more material, including males of $A$. latus and $A$. kaszabi, is examined.

USS patterns vary in the new species, since intermediate seta US7 ranges considerably in its position. In particular, patterns $6-1-7,6-1-7$ or $7-7$, and $6-1-8$ or $7-8$ have been found in three, 14 , and three specimens examined, respectively.

\section{Aristopus picturatus (Andrewes, 1920), comb.n.} Figs 19, 40-41, 51, 58-59.

Andrewes, 1920: 447 (Cosmodiscus; Nagpur, Maharashtra, India); 1921: 345; 1930: 131

MATERIAL. $60^{7} \sigma^{7}, 2$, 2 (ZISP), Sri Lanka, Vilpattu, Talawila, 8-9.X.1982 (Medvedev); 2 \%क (SIEE), Sri Lanka, Anuradhapura env., Amaya Lake Hotel, at light, 16.X.2009 (S. Dementiev).

DIAGNOSIS. The only Oriental species of Aristopus sharing substantial features such as the presence of parascutellar seta and discal seta $\mathrm{d} 2$ on the elytra with African and Madagascan congeners. The elytral pattern as for the previous species, except that the humeral elytral macula is long, running on basal $1 / 2-3 / 5$ and rather narrowly separated (vs. short and widely separated) from the anterior preapical macula on intervals 4 and 5 .

REDESCRIPTION. BL 5.9-7 mm. Body (Fig. 19) shiny, reddish brown to brown black, clypeus entirely or in anterior half, labrum, mouthparts, legs and antennae red; explanate lateral margins of pronotum, elytral epipleura and pattern reddish yellow. Elytral pattern as for the previous species, except as follows: humeral spot long, running on basal 1/2-3/ 5 and spanning intervals 5-8 anteriorly and 5-7 behind; anterior and posterior preapical spots fused along stria 3 . Dorsal microsculpture (in specimens examined) absent from the forebody, elytral microsculpture consisting of extremely fine and very dense transverse lines and thence slightly iridescent.

Head with fairly large, almost hemispherical eyes. Frontal sulci short, deep and strongly divergent, not reaching anterior supra-ocular seta. Labrum apically subsinuate. Antennae just reaching or barely surpassing pronotal base. Mentum tooth medium-sized, truncate and subsinuate.

Pronotum subquadrate, two fifths to half wider than long, PW/PL 1.40-1.50 (1.47, $\mathrm{n}=7)$, than two thirds wider than head, PW/HW 1.63-1.70 (1.67). Sides rounded, explanate lateral margin slightly reflexed, narrow to indistinct in front of anterolateral seta, increasingly wide toward and moderately wide at basal angles, these obtuse and blunt; lateral bead fine, entire, vague at basal angles. Base wider than apex, PB/PA 1.30-1.46 (1.41), truncate medially, slightly oblique and finely beaded outside basal sulci. These deep, parallel, running on basal third. Apical margin truncate to slightly concave; apical angles obtuse and blunt, barely projecting or not; apical bead obliterate in middle third (and vestigial laterally in specimens examined). Median line very fine. Disc convex and smooth, basal sulci densely, moderately to vaguely punctate at bottom, without or with a few punctures at sides, explanate lateral margin punctate in a similar manner.

Elytra, ventral side and legs as for previous species except as follows, EL/EW 1.34-1.38 (1.36), EW/PW 1.241.32 (1.28), oval, more dilated apicad. Humeral tooth nearly indistinct. Intervals flat, convex apically. Parascutellar seta at base of stria 2, discal seta $\mathrm{d} 2$ adjoining stria 2 tree fifths from base. USS: $6-1-7$ or $7-7$, i.e., intermediate seta (US7), distinctly or much closer to US6 than to US8; US10 large, adjoining stria 8 and slightly separated from stria 9 .

Prosternal process without or with vestigial yet distinct apical bead. 
Legs. Protibia with three latero-apical spines. Metafemur bisetose at anterolateral margin. Mesotibia with inner setal brush consisting of $7+1$ or $8+1$ setae; metatibia with three spiniform setae.

Aedeagus (Figs 40-41, 51, 58-59): Aedeagus more curved ventrad than in $A$. humeratus sp.n., with internal sac and parameres different in shape.

GEOGRAPHIC DISTRIBUTION. India: Maharashtra, Uttar Pradesh, Orissa, Andhra Pradesh; first recorded in Sri Lanka.

HABITATS AND HABITS. No data, except that the specimens examined have been collected at light.

COMMENTS. The adults from two different local populations in Sri Lanka have been found to be considerably different in the ratio PB/PA, being either $1.30-1.37(\mathrm{n}=2)$ or $1.42-1.46(1.44, \mathrm{n}=5)$ in specimens from Anuradhapura or Vilpattu, respectively

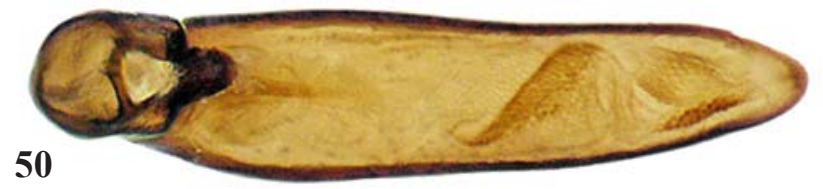

51
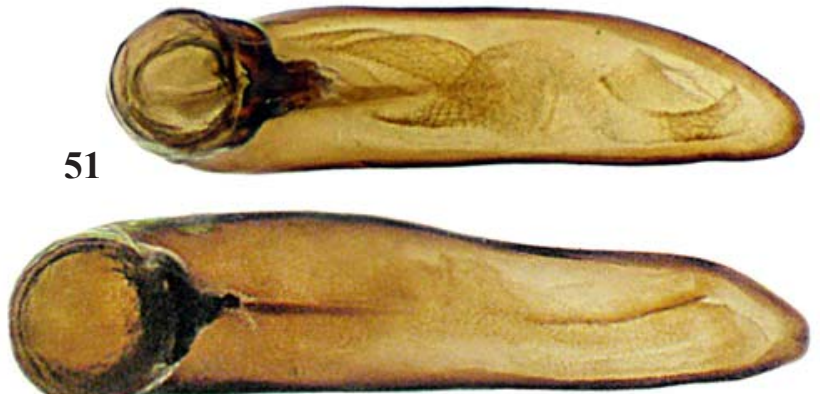

52
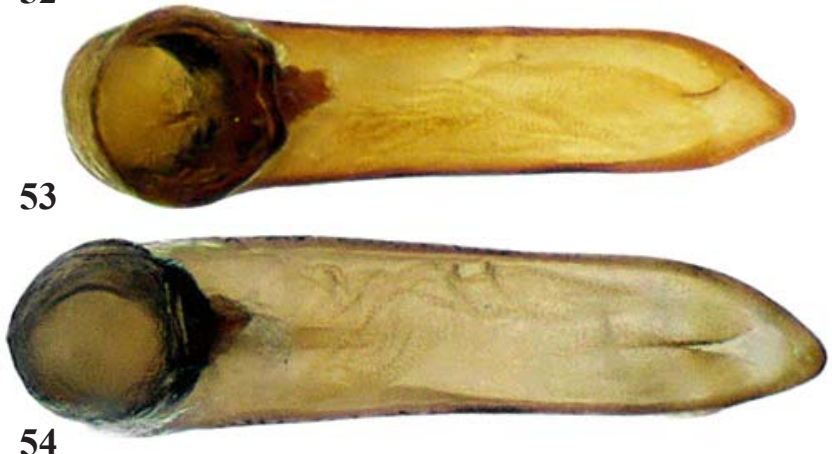

54

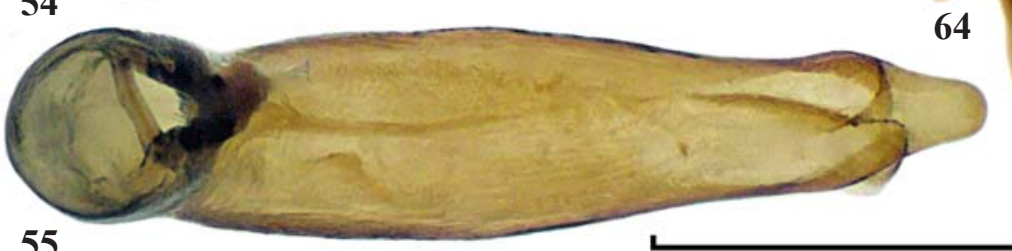

\section{Cosmodiscus Sloane, 1907}

Sloane, 1907: 372; Andrewes, 1920: 445; 1921: 345; 1930 : 131; Straneo, 1940: 211; 1982: 339; 1983: 316; Jeannel, 1948: 442; Will, 2020a: 165; Habu, 1981: 47. - Celioinkosa Straneo, 1951: 238; 1982: 340-341; 1995: 185 (type species: Celioschesis kivuana Burgeon, 1935, by original designation), syn.n. typy).

Type species: Cosmodiscus rubripictus Sloane, 1907 (by mono-

DIAGNOSIS. As for Aristopus except as follows: body more robust, mandibles short, laterally rounded, dorsally depressed inside a fine lateral carina, eyes hemispherical, very prominent, pronotum with entire apical bead, without basal bead (sometimes vestigial basal bead traceable outside basal sulci), elytral parascutellar seta and discal seta $\mathrm{d} 2$ present or not; posterior group of USS containing eight US, abdominal sternite IV without obligatory paramedian seta.
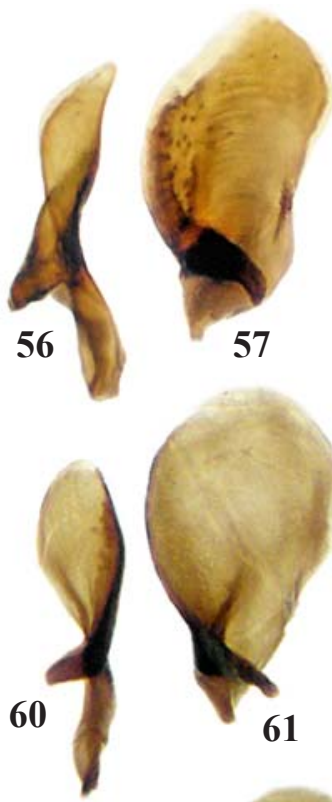

57

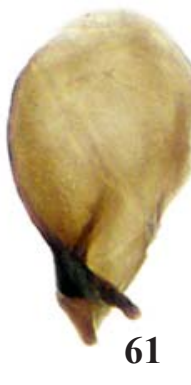

(1

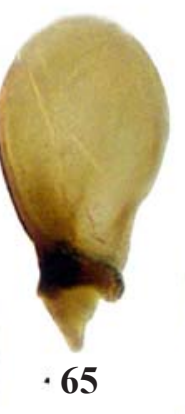

66

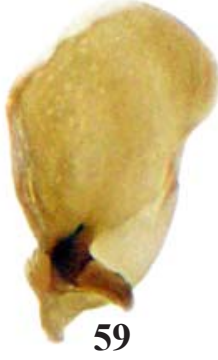

58
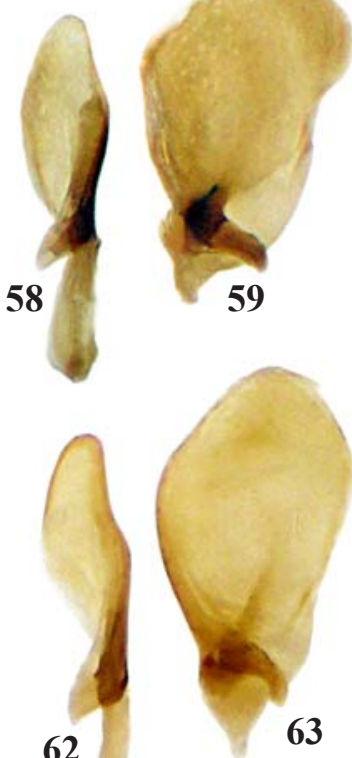

62
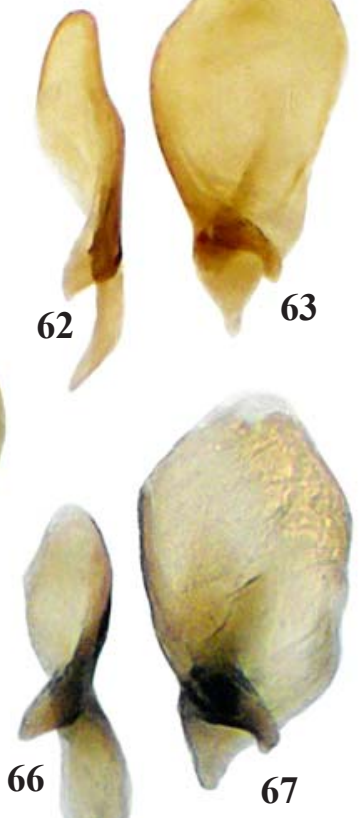

Figs 50-67. Aedeagus: 50, 56-57 - Aristopus humeratus sp.n., paratype $\bigcirc^{7}$ from env. Pai, Thailand; 51, 58-59-A. picturatus, $\bigcirc^{7}$ from Vilpattu, Sri Lanka; 52, 60-61 - Cosmodiscus platynotus; 53, 64-65 - C. rufoapicalis sp.n., holotype; 54, 62-63 - C. louwerensi, paratype; 55, 66-67-C. mirei; 50-55 - median lobe, ventral aspect; 56, 58, 60, 62, 64, 66 - right paramere, left aspect; 57, 59, 61, 63, 65, 67 - left paramere, right aspect. Scale bar: $1 \mathrm{~mm}$.

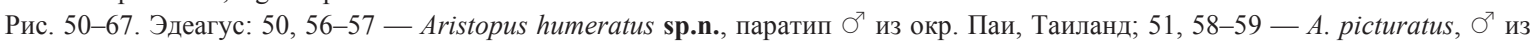
Вильпатту, Шри Ланка; 52, 60-61 - Cosmodiscus platynotus; 53, 64-65 - C. rufoapicalis sp.n., голотип; 54, 62-63 - C. louwerensi, паратип; 55, 66-67 - C. mirei; 50-55 - средняя доля вентрально; 56, 58, 60, 62, 64, 66 - правая парамера слева; 57, 59, 61, 63, 65, 67 - левая парамера справа. Масштаб: 1 мм. 
REDESCRIPTION. Body appearance and most characters as for Aristopus, except for the following few: body more robust (Figs 21-24, 68-70); head with eyes that are more prominent and thence with nearly right angle between gena and neck, mandibles peculiar in shape. Pronotum and elytra mostly subequally wide at bases, pronotum impunctate or indistinctly punctate (to densely punctate along base in at least some Afrotropical species), with lateral margin slightly reflexed and very widely explanate towards base. Elytra wide at bases, with stria 7 adjoining basal ridge at a distance from humeral angle. Legs stronger, protibia with 3-4 lateroapical spines, mesotibia with 4-5 anterolateral spiniform setae and inner setal brush consisting of 7-8 setae. Basal two protarsomeres more strongly toothed at latero-apical angles in female, inner (anterior) tooth being very large, much larger than outer one.

Median lobe of aedeagus more or less geniculate, with a distinct longitudinal median carina in the curve of ventral margin; apex small, triangular and curved ventrad. Internal sac unarmed. Left paramere widely rounded, right one less so.

Abdominal urite VIII in female as in Figs 32-33. Female genitalia and reproductive tract (examined in C.platynotus) as for Aristopus, except only that ventral membrane of urite IX, laterotergite and gonosubcoxite are glabrous; gonocoxite is slightly different (Fig. 35): slenderer, more curved, with basolateral angle more attenuated; single ventral ensiform seta only present.

For other distinctive features see 'Diagnosis'.

GEOGRAPHIC DISTRIBUTION. Throughout Paleotropical realm, east to Australia and southeastern Palearctics (Japan).

HABITATS AND HABITS. Darlington [1962] mentioned that he collected two species, C. rubripictus and $C$. brunneus Darlington, 1962, 'among dead leaves and debris on the ground in rain forest' and I have taken twelve out of totally 13 specimens at light at the edges of monsoon forests.

COMMENTS. Ten species are here recognized within the genus: C. rubripictus Sloane, 1907 (Australian and Papuan), C. brunneus (Papuan), six Oriental species, including new two (see below), C. platynotus (Bates 1873), C. rufolimbatus Jedlička, 1936 ( = C. louwerensi Straneo, 1940, syn.n.), C. umeralis Andrewes, 1937, and three species from Central and West Africa (= Celioinkosa). Darlington [1962] supposed C. rufolimbatus and C. louwerensi to be only forms of, i.e., conspecific with, C. rubripictus.

\section{Cosmodiscus platynotus (Bates, 1873)}

Figs 21, 32-33, 35, 42-43, 52, 60-61.

Bates, 1873: 283 (Stomonaxus; Nagasaki); Andrewes, 1920: 447; 1921: 345; 1930: 132; 1933: 341; Straneo, 1938b: 7, 12; 1940 211-212; Habu, 1981: 47. — dilaticollis Bates, 1892: 351 (Stomonaxus; Karin Cheba, Burma).

MATERIAL. Eleven specimens (SIEE, D. Fedorenko leg.): 오, Vietnam, Lao Cai Province, Hoang Lien Son Mt. Ridge, env. Phang Xi Pang Mt, Tram Ton, $\mathrm{h}=1950-2100 \mathrm{~m}, 15-30$. VII.2007; 40 $0^{7} \mathrm{O}^{7}$, 4 오, Lam Dong Province, Bi Doup-Nui Ba Nature Reserve, env. Long Lanh, $12^{\circ} 10^{\prime} 44^{\prime \prime} \mathrm{N} / 108^{\circ} 40^{\prime} 44^{\prime \prime} \mathrm{E}, \mathrm{h}=1400-1600 \mathrm{~m}$, at light, 7-20.IV.2008 or 28.IV-10.V.2009; $\sigma^{7}$, ,, $35 \mathrm{~km} \mathrm{NW}$ of Bao Loc, Loc Bao env., $\mathrm{h}=650 \mathrm{~m}, 11^{\circ} 50^{\prime} 12^{\prime \prime} \mathrm{N} / 107^{\circ} 38^{\prime} 25^{\prime \prime} \mathrm{E}$, at light, 17 22.IV.2012; $20^{7} O^{7}$, ㅇ (MPSU), Quang Binh Province, Minh Hoa [=Quy Dat] District, Ke Bang, env. Yen Hop, at light, 17.IV.1999 (S. Kruskop).

DIAGNOSIS. See the respective section for C. rufoapicalis sp.n. below.

REDESCRIPTION. Very slightly different from $C . r u$ foapicalis sp.n. in the following characters: BL $6.3-8.5 \mathrm{~mm}$. Elytra without pale preapical markings (Fig. 21). Head without microsculpture.
Head: Frontal sulci slightly divergent, disappearing on a level with anterior supra-ocular setae. Pronotum barely longer, PW/PL 1.67-1.76 (1.73, n=7), about as wide as head, PW/ HW 1.96-2.09 (2.01); PB/PA 1.61-1.73 (1.68). Disc convex and smooth; basal sulci more shallow; punctation mostly traceable in basal sulci only.

Elytra barely longer, EL/EW 1.27-1.38 (1.32), EW/PW 1.03-1.11 (1.07). Parascutellar seta present, discal setae missing. USS: $6-1-8$, posterior group of US continuous.

Underside: Abdominal sternites IV-VII finely and densely striate along bases at sides, not or less distinctly so medially. Prosternum not beaded.

Legs. Protibia with four latero-apical spines. Mesotibia with four spiniform anterolateral setae, inner setal brush consisting of $6+1$ or $7+1$ setae; metatibia with $4-5$ spiniform setae. Mesotarsomere 1 and metatarsomeres 1 and 2 externally sulcate.

Aedeagus (Figs 42-43, 52, 60-61): median lobe in ventral view narrower in apical than in basal part, with a distinct ventral carina. 35.

Abdominal urites VIII and IX in female as in Figs 32-33,

GEOGRAPHIC DISTRIBUTION. Southern and northeastern India (Sikkim), Myanmar, Sumatra, Java, Japan. The species is here first reported from Vietnam.

HABITATS AND HABITS. Great majority of the specimens have been taken at lights positioned at the edges of monsoon broad-leaved forests.

COMMENTS. One of totally eight examined specimens from the Bi Doup - Nui Ba Nature Reserve has the elytra lacking parascutellar setigerous pore.

\section{Cosmodiscus rufoapicalis Fedorenko, sp.n.} Figs 22, 44-45, 53, 64-65.

MATERIAL. Holotype $\sigma^{7}$ (ZMMU) labelled: 'Vietnam, Gia Lai Province/ $\sim 55 \mathrm{~km}$ ENE Pleiku, $14^{\circ} 17^{\prime} 45^{\prime \prime} \mathrm{N} / 108^{\circ} 26^{\prime} 57^{\prime \prime} \mathrm{E}, \mathrm{h}=600$ $\mathrm{m}$, at light, 8-20.V.2017 40 km ENE of Pleiku/ $14^{\circ} 17^{\prime} 45^{\prime \prime} \mathrm{N} /$ $108^{\circ} 26^{\prime} 57^{\prime \prime} \mathrm{E}$, Kon Ka Kinh Nat[io]n[al]. Park, / h=600 m, at light 8-20.V./ D.Fedorenko leg. 2017'.

DIAGNOSIS. Very similar to C. platynotus in body shape and proportions, being distinctive in having elytral apices and suture apically pale, red, and the combination of parascutellar seta missing (vs. present) and discal seta $\mathrm{d} 2$ present ( $v s$. absent). Aedeagus is slightly different, in ventral view parallel-sided ( $v s$. narrower in apical than in basal half), with apex more symmetrical, and shorter in lateral view.

DESCRIPTION. BL 7.4 mm. Body (Fig. 22) shiny black, lateral bead of pronotum, reflexed lateral margin of elytra, elytral interval 1 in apical third, latero-apical macula outside stria 3 between apical fifth mesally to apical third laterally, legs, antennae, mouthparts and labrum red; explanate margins of pronotum translucent with red. Underside black, prothorax ventrally and abdominal sternite along apical margin slightly reddish. Dorsal microsculpture meshed, very superficial, isodiametric on head, moderately transverse on pronotum, very transverse on elytra, granulate in marginal groove of the latter, not well traceable here and there on head and at middle of both pronotal disc and elytra, distinct over explanate margins of pronotum.

Head with abruptly prominent eyes and a nearly imperceptible neck constriction on sides. Frontal sulci short, deep, very slightly diverging basad, disappearing on a level with anterior supra-ocular setae. Labrum truncate, with indistinct sinuation at middle. Antennae short, not reaching pronotal base.

Pronotum transverse, obtrapezoidal, almost twice as wide as long and as much as wide as head, PW/PL 1.90, PW/HW 
1.89. Sides rounded, lateral margins only slightly reflexed yet very widely explanate toward base, borderline between explanate margins and disc obliterate basally. Margins finely beaded throughout except basally, apical bead very distinct, medially flat and much wider than laterally. Base truncate and gently trisinuate, much wider than apex, PB/PA 1.63; basal angles obtuse and rounded, but minutely toothed. Basal sulci deep, indistinctly converging apicad, running on basal third, more shallow basally. Apical margin rather deeply concave between obtuse and rounded apical angles. Median line fine yet distinct, nearly entire, obliterate just basally. Disc convex and smooth; basal sulci, basal angles and explanate margins closer to lateral beads in apical half very finely and very sparsely punctate.

Elytra short, a fourth longer than wide, EL/EW 1.27, almost as wide as pronotum, EW/PW 1.08, widely oval, almost parallel-sided in middle third, broadest slightly before middle; apices rounded combined. Humeri rather distinct, with a distinct small tooth; basal ridge transverse, barely convex outside stria 3 , humeral angle very obtuse. Striae entire, deep, minutely crenulate, much deeper apically and toward lateral margin. Intervals convex, very so in apical third and toward lateral margin, those 1 and 2 subconvex on disc. Parascutellar seta missing, interval 3 two-fifths from apex with a distinct seta $\mathrm{d} 2$, which is subequally distant from striae 2 and 3 . Stria 7 with two apical setae. USS: $6-1-8$, setigerous pores of posterior group (US8-15): 4-4, US3 adjoining stria 9, US11 large, adjoining striae 8 and 9.

Underside finely and rather densely punctate, except for along middle and prothorax. Sides of abdominal sternites IV-VII finely and densely striate along bases. Prosternum without median groove, prosternal process apically beaded.

Legs. Protibia with three latero-apical spines. Metafemur bisetose. Mesotibia with four spiniform anterolateral setae, inner setal brush consisting of $6+1$ setae; metatibia with single spiniform seta at middle of external ridge. Meso- and metatarsomere 1 externally sulcate.

Aedeagus (Figs 44-45, 53, 64-65): median lobe in ventral view parallel-sided, with a slight ventral carina.

NAME. Refers elytra with red apex against black.

GEOGRAPHIC DISTRIBUTION. Known from the type locality only.

HABITATS AND HABITS. The only specimen has been taken at light.

\section{Cosmodiscus rufolimbatus Jedlička, 1936} Figs 23-24.

Jedlička, 1936: 103 (Mindanao, Philippines); Straneo, 1940: 217; Darlington, 1962: 514. - louwerensi Straneo, 1940: 215 (Saleier Is., S Celebes); Darlington, 1962: 515, syn.n.

MATERIAL. Holotype + (NHML) without right antennomeres 2-11, labelled: 'Type', circle margined with red; 'Philippine Is. Coll.Bottcher./ BM.1929-201.', 'Philippine Islands/ Mindanao 5:II:1915/ Coll. Bottcher', 'Cosmodiscus rufolimbatus/ type sp.n./ det. ING.JEDLIČKA', 'NHMUK 014486294'. Paratype O' (NHML) of $C$. louwerensi (without left antennomeres 4-11 as a result of vital loss) labelled: 'Isl. Saleier/ Somarisi', red 'Paratypus', 'Cosmodiscus/ Louwerensi n.sp./dët. ing. Straneo', 'H.E.Andrewes Coll./ B.M.1945-97.', 'NHMUK 014486387'.

DIAGNOSIS. See the key below.

REDESCRIPTION. BL 6.3-7.3 mm. Body (Figs 23-24) Black, pronotum rather narrowly reddish along sides, slightly more so towards base. Scutellum and elytral base slightly reddish. Elytral sutural interval in apical third, extreme apices, lateral margin outside stria 7 , interval 7 in about basal eighth and behind middle deep red, with pale colour slightly dilated in form of an oblique preapical macula spanning intervals 6 to 4 in a bit more than apical fourth. Mouthparts, labrum, antennomeres 1-3 and legs reddish-yellow, tibiae and tarsi slightly infuscated, reddish brown, antennomeres 4 11 less so. Head shiny, without microsculpture, but clypeus and anterior half of frons with very superficial isodiametric meshes; pronotum with very superficial wide meshes becoming more distinct and moderately transverse toward sides of base, elytral microsculpture superficial, consisting of rather narrow transverse meshes.

Head. Frontal sulci short, slightly diverging, moderately deep, almost reaching level of anterior supra-ocular seta. Neck constriction hardly traceable on sides. Labrum subtransverse and barely sinuate. Antennae rather short, not reaching pronotal base.

Pronotum subquadrate, transverse, PW/PL 1.77, PW/ HW 1.85. Sides rounded, explanate lateral margins very wide basally to no apically. Base truncate, half wider than apex, PB/PA 1.53, subsinuate between basal sulci and lateral margin; basal angles obtuse, with only a trace of apical tooth. Apex evenly and rather slightly sinuate between obtuse and slightly projecting apical angles. Groove inside fine lateral bead narrow, very sparsely and vaguely punctate. Basal sulci fine, moderately deep, parallel, running on basal two fifths, reaching base, finely and sparsely punctate at bottom (rather crenulate), median line fine, obliterate in basal fifth

Elytra wide, EL/EW 1.30, subparallel-sided, barely wider than pronotum, EW/PW 1.18, with a distinct preapical sinuation and a small re-entrant angle between extreme apices. Base slightly oblique, humeri rounded yet distinct, with a very microscopic spiniform tooth, basal ridge nearly straight and transverse, humeral angle very obtuse and almost rounded. Striae fine, deep, crenulate; intervals barely convex on disc, convex laterally, very convex in apical third. Lateral groove uneven, densely to confluently punctate and thence partly obliquely cross-striated. USS: $6-1-8 / 6-1-8$.

Underside moderately and rather densely punctate along sides, sides of abdomen less so, propleura nearly impunctate. Prosternal process without marginal bead, inclination convex.

Legs. Protibia with three latero-apical spines and four posterior spines. Mesotibia with four spiniform anterolateral setae and one posterolateral seta on a level with distal anterolateral seta; inner setal brush consisting of $6+1$ setae. Metatibia with two lateral setae. Metafemur bisetose.

GEOGRAPHIC DISTRIBUTION. Known to-date from Mindanao, Philippines, and Selayar Is., southern Celebes.

HABITATS AND HABITS. No data.

COMMENTS. The examined male paratype of $C$. louwerensi (Fig. 24) is different from the male holotype of $C$. rufolimbatus in the following. Body colouration slightly more contrasting, with pale red pattern more distinct and more developed. It covers slightly wider lateral margins of the pronotum, elytral sutural interval in apical fourth, extreme apices, lateral margins outside stria 6 , interval 6 in basal fourth, and intervals 4-6 in about apical third; this preapical spot being about same size, yet almost straight at anterior margin. Tibiae barely infuscated. Pronotal basal sulci more shallow, almost obliterate in their basal two fifths; a vestigial basal bead traceable except for in middle and lateral fifths; basal angles obtuse and rounded; explanate lateral margin rather wide ( $v s$. absent) in front of anterolateral seta. Elytral striae wider, intervals slightly convex on disc. Lateral groove nearly smooth. USS: 7-8/ 6-1-8. Prosternal process with a faint bead at apex. Propleura smooth. Leg setation: Mesotibia with 4-5 anterolateral setae, posterolateral seta just distal to distal anterolateral seta, inner setal brush consisting of $7+1$ setae; metatibia with three lateral setae. 
These differences do not exceed the limits of individual or geographic variability of respective characters in other examined species of the genus. Therefore, they are insufficient to maintain species status of the two species discussed, for which reason both these names are here recognized as conspecific.

\section{Cosmodiscus sharovae Fedorenko, sp.n.} Fig. 68.

MATERIAL. Holotype 9 (ZMMU), labelled: 'Vietnam, Gia Lai Province/ $\sim 55 \mathrm{~km}$ ENE Pleiku, $14^{\circ} 17^{\prime} 45^{\prime \prime} \mathrm{N} / 108^{\circ} 26^{\prime} 57^{\prime \prime} \mathrm{E}, \mathrm{h}=600$ $\mathrm{m}$, at light, 8-20.V.2017 40 km ENE of Pleiku/ 14 ${ }^{\circ} 17^{\prime} 45^{\prime \prime} \mathrm{N} /$ $108^{\circ} 26^{\prime} 57^{\prime \prime} E$, Kon Ka Kinh Nat[io]n[al]. Park,/ h=600 m, at light 8-20.V./ D.Fedorenko leg. 2017'.

DIAGNOSIS. Body (Fig. 68) without maculate elytral pattern, pronotum very transverse, subquadrate, with base much narrower than that of elytra; these having neither parascutellar seta nor discal setae. This species is very similar to $C$. umeralis, except only that the elytra lack the parascutellar seta.

DESCRIPTION. As for C. rufoapicalis sp.n., except as follows. BL $6.9 \mathrm{~mm}$. Head black, indistinctly reddish; pronotum dark brown in the middle of disc, becoming gradually paler toward lateral margins and less so toward base and apex, so that pronotum widely red along sides; elytra rather pale, reddish brown, outside stria 4 and in apical fourth, with pale colour gradually merging into dark brown toward suture; clypeus, meso- and metathorax laterally, and abdomen reddish brown; body otherwise pale, including, labrum, apical margins of abdominal sternites, and apical half of abdominal sternite VII pale red. Dorsal microsculpture obliterate on neck, and more transverse on pronotum.

Head: neck constriction missing. Frontal sulci short, deep, strongly diverging basad, not reaching the level of anterior supra-ocular setae. Labrum subsinuate. Antennae longer, slightly surpassing pronotal base.
Pronotum very transverse, quadrate, PW/PL 1.75, much wider than head, PW/HW 1.70. Explanate lateral margins narrow in front of anterolateral seta, increasingly wide behind, very wide basally. Base narrow, only a third wider than apex, $\mathrm{PB} / \mathrm{PA}$ 1.31, much narrower than elytral bases combined, conspicuously oblique outside basal sulci. Apical margin evenly concave, apical angles obtuse, with apices rounded. Median line obliterate basally and apically. Basal sulci deep, running on basal two fifths, finely punctate, more densely and more distinctly at bases, with only a trace of basal bead outside them; explanate margins just inside lateral beads with minute and very sparse punctures.

Elytra about a third longer than wide, EL/EW 1.36, distinctly wider than pronotum, EW/PW 1.30, broadest behind middle, with subtle preapical sinuation. Humeri without tooth, humeral angle very obtuse and rounded. Intervals subconvex, very convex in apical fourth. Neither parascutellar seta nor discal setae. USS: 6-1-8, posterior group of USS continuous.

Underside: Prosternal process slightly pointed at apex, without bead.

Legs. Metatibia with two spiniform setae at outer margin. Mesotarsomere 1 and metatarsomeres 1 and 2 externally sulcate.

NAME. I am honoured to name this species after the late Inessa Khristianovna Sharova, for her major contribution to carabidology, especially ecology of ground beetles.

GEOGRAPHIC DISTRIBUTION. Known from the type locality only.

HABITATS AND HABITS. The only specimen has been taken at light.

\section{[5. Cosmodiscus umeralis Andrewes, 1937]} Fig. 69.

Andrewes, 1937: 38 (Bali); Straneo, 1940: 217; Darlington, 1962: 516.

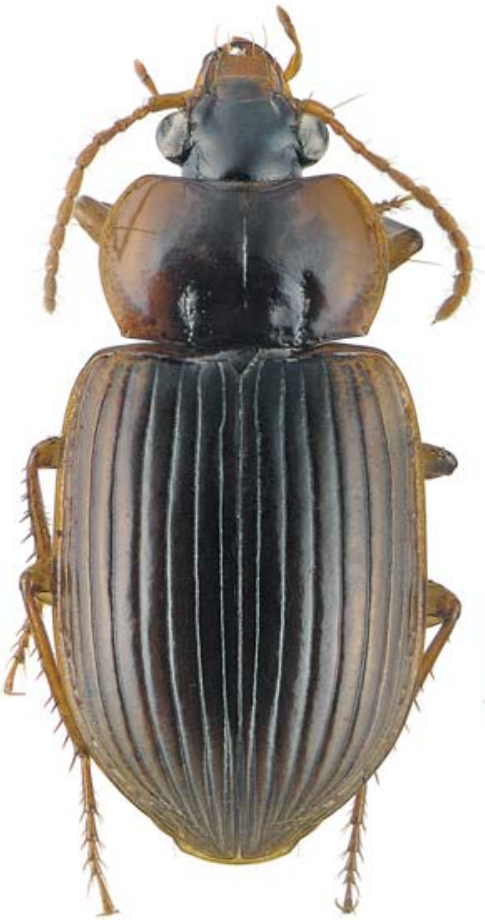

68

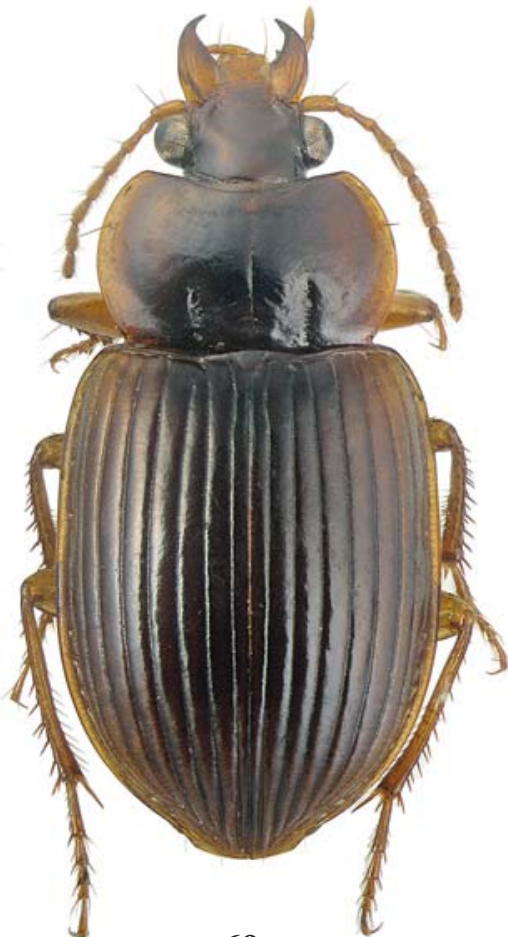

69

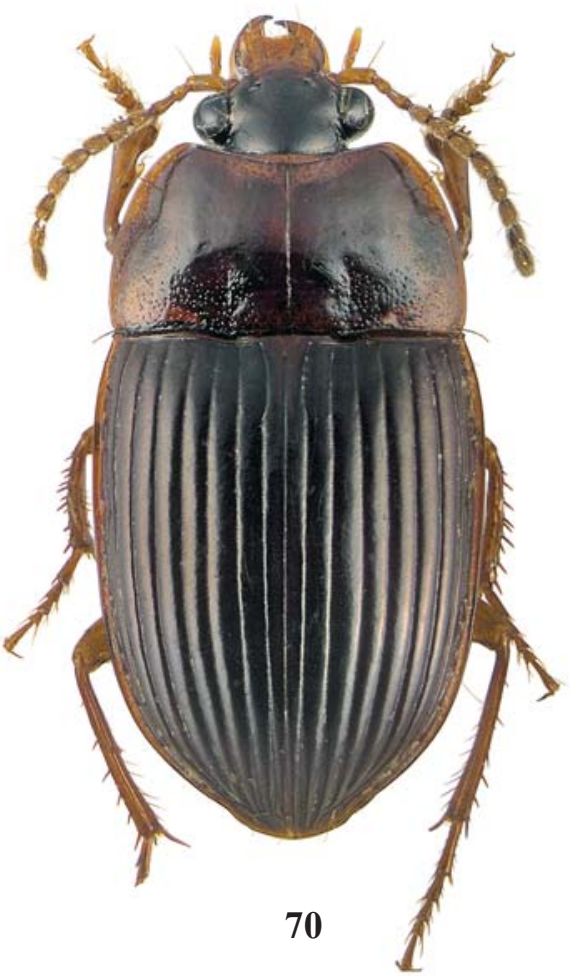

Figs 68-70. Dorsal habitus of Cosmodiscus spp.: $68-$ C. sharovae sp.n., holotype; $69-$ C. umeralis, holotype; 70 - C. mirei, paratype $\sigma^{7}$. Рис. 68-70. Габитус дорзально Cosmodiscus spp.: 68 - C. sharovae sp.n., голотип; 69 - C. umeralis, голотип; 70 - C. mirei, паратип フ' $^{\prime}$ 
MATERIAL. Holotype 9 (NHML), with labels: 'BATOERITI/ E. BALI', Ex Coll./ C.J. Louwerens', 'Type', 'Cosmodiscus/ umeralis/ Type Andr./ H.E. Andrewes det.', 'H.E.Andrewes Coll./ B. M.1945-97.', 'NHMUK 014518070'.

DIAGNOSIS. Very much like $C$. sharovae sp.n., but for parascutellar seta missing (Fig. 69).

RE-DESCRIPTION. BL $7.2 \mathrm{~mm}$. Head and pronotum dark brown, elytral disc less so. Pronotum rather widely along sides, legs, mouthparts, including labrum, and antennomeres 1-3 reddish-yellow; antennomeres 4-11 indistinctly darker, brownish. Elytra gradually paler toward both lateral margins and apices, reddish in apical fourth and outside striae 5-6, with pale colour more distinct at humerus, thus forming rather small and vague humeral spot on intervals 7,8 and almost indistinctly on 6 . Ventral side reddish brown, thoracic ventrites 1-3 reddish yellow along middle. Head with very superficial isodiametric meshes, pronotal microsculpture superficial and moderately transverse, elytral microsculpture consisting of very superficial and very narrow meshes, almost transverse lines. Elytral striae at bottom and lateral groove with coarse isodiametric meshes.

Head: Frontal sulci as in C. rufolimbatus.

Pronotum small, transverse, quadrate, four fifths wider than long, PW/PL 1.80, much wider than head, PW/HW 1.66. Base narrow, much narrower than elytral bases combined, only a fourth wider than apex, PB/PA 1.26, truncate medially, slightly oblique and almost indistinctly sinuate in lateral third; apex evenly sinuate between obtuse apical angles. Sides rounded, basal angles obtuse, each with a minute blunt tooth. Explanate lateral margins very slightly reflexed, increasingly wide toward base, very wide basally. Groove inside fine lateral bead narrow, very sparsely and vaguely punctate. Basal sulci moderately deep, deeper apically, barely diverging apicad, running on basal two fifths, reaching base, finely and sparsely punctate at bottom (rather crenulate). Median line fine, obliterate in basal third.

Elytra about a third longer than wide, EL/EW 1.32, distinctly wider than pronotum, EW/PW 1.28, broadest behind middle. Striae deep, rather wide, indistinctly crenulate, deeper laterally and apically, intervals subconvex on disc, convex laterally and very convex in apical fourth. Lateral groove smooth. Parascutellar seta present. USS 6-1-8/ 6-1-8.

Underside: Prosternal process without marginal bead, inclination convex. Propleura impunctate, ventral side otherwise moderately and rather densely punctate along sides.

Legs: protibia with three latero-apical and four posterior setae, mesotibia with five anterolateral setae and one posterolateral seta on a level with or just distal to distal anterolateral seta, inner setal brush consisting of $8+1$ setae, metatibia with three lateral setae. Metatibia with two spiniform setae at outer margin. Mesotarsomere 1 and metatarsomeres 1 and 2 externally sulcate.

GEOGRAPHIC DISTRIBUTION. Known from the type locality only.

HABITATS AND HABITS. No data.

Key to the ORIENTAL SPECIES OF ARISTOPUS AND CosmodisCus (species in square brackets have not been recorded in Vietnam)

1(8) Pronotal apical bead medially interrupted to indistinct. Abdominal sternite IV with one pair of obligatory medial setae. Eyes smaller, pronotum less transverse, 1.40-1.55 times as wide as long. Elytral pale pattern consisting of a narrow lateral margin up to apex and two, quadrate, slightly longitudinal spots on intervals $4-5$ and $2-3$ in apical two fifths, adjoining along stria 3 and separated from both suture and apex, without or with (Figs. 19-20) a distinct humeral spot. Dorsal microsculpture indistinct, with very dense transverse lines hardly traceable on elytra Aristopus LaFerté-Sénectère, 1853

2(3) Elytron with parascutellar seta at base of stria 2, discal seta d2 adjoining stria 2 about three fifths from base; pale humeral spot on intervals 5-7 oblong, almost reaching to slightly surpassing middle. Frontal sulci short. - India, Sri Lanka ....... 2. A. picturatus (Andrewes, 1920), comb.n.

3(2) Elytron without parascutellar or discal setae; humeral pale spot smaller or missing.

4(5) Humeral pale spot spanning intervals 5- or 6-8 in basal fourth or fifths. Frontal sulci long, reaching posterior supra-ocular seta. Pronotal apical bead obliterate. Indochina; Nepal

1. A. humeratus sp.n.

5(4) Elytron without humeral spot. Frontal sulci short, not reaching anterior supra-ocular seta. Pronotal apical bead traceable laterally.

6(7) Species from Myanmar ... [?.A. latus (Andrewes, 1947)]

7(6) Species from Taiwan ..... [A. kaszabi (Jedlička, 1954)]

(8)1 Pronotal apical bead entire. Abdominal sternite IV without medial setae. Eyes larger, pronotum very transverse, ca. 1.71.9 times as wide as long. Elytra uniform black to rather pale brown or with pale pattern other than above (Figs 21-23, 6870), generally marginal, with vestigial humeral spot, small preapical spot outside stria 3 , merging into lateral margin outside stria 6 or 7 and mostly separated by intervals 2 and 3 from apical sutural stripe. Dorsal microsculpture meshed, superficial yet traceable, isodiametric on head, slightly to moderately transverse on pronotum, very transverse on elytra Cosmodiscus Sloane, 1907

9(20) Elytra uniform black or brown, or red along sides up to apices.

10(15) Pronotum trapezoidal or nearly so, broadest distinctly behind middle, PLw/PL 0.57-0.68, with base much wider than apex, PB/PA 1.53-1.73, and almost as wide as elytral basses combined. Dorsum uniform black or pronotum and elytra red along sides.

11(14) Elytra with parascutellar seta at base of stria 2, without discal setae.

12(13) Dorsum black (Fig. 21). Pronotum at base very wide, about two thirds as wide as at apex. BL. $6.3-8.5 \mathrm{~mm}$. India to Japan ................ 1. C. platynotus (Bates, 1873)

13(12) Dorsum black, pronotum and elytra pale along sides (Fig. 23). Pronotum at base narrower, slightly more than half wider than at apex. BL. 6.3-7.3 mm. - Philippines and southern Celebes ....... [3. C. rufolimbatus Jedlička, 1936]

14(11) Elytra without parascutellar seta at base of stria 2, but with discal seta at middle of interval 3 a third from apex. Pronotum very transverse. Elytra black, with reflexed lateral margin, small latero-apical spot and suture in apical third red. BL 7.4 mm. - Central Vietnam ............ 2. C. rufoapicalis sp.n.

15(10) Pronotum transverse, subquadrate, distinctly narrower than elytra, broadest at middle PLw/PL 0.46-0.48, with base slightly narrower than apex, PB/PA 1.26-1.31, and much narrower than elytral basses combined (Figs 6869). Elytra rather dark brown, gradually paler toward lateral margin and toward apices, each without or with a vague humeral spot, without discal setae.

16(19) Pronotum small and very transverse, PW/PL 1.751.80 , widely reddish along sides, elytra short, EL/EW $1.32-1.36$.

17(18) Elytral parascutellar seta present. Pronotum rather narrowly pale along sides. BL $7.2 \mathrm{~mm}$. - Bali .............

[5. C. umeralis Andrewes, 1937]

18(17) Elytral parascutellar seta missing. Pronotum pale in lateral fourth. BL $6.9 \mathrm{~mm}$. - Central Vietnam 
19(16) Pronotum larger and less transverse, PW/PL ca. 1.60, narrowly reddish along sides, elytra slightly longer, EL/ EW 1.40, with parascutellar seta each. - New Guinea [C. brunneus Darlington, 1962]

20(9) Elytra black, with reddish yellow pattern including large humeral spot, lateral margin outside stria 6 in basal two thirds and oblique band starting behind middle laterally and reaching suture a fourth from apex. Pronotum obtrapezoidal, broadest distinctly behind middle, PLw/ PL 0.65. - Northern Australia and New Guinea.......... [C. rubripictus Sloane, 1907]

Acknowledgements. I am very grateful to Dr. Max Barclay (NHML), Dr. Roman Dudko (SZM), Dr. Boris Kataev (ZISP), and Dr. Kirill Makarov (MPSU) for the loan of material under their care and to Igor Melnik (Moscow) for donating specimens. My sincere thanks are also to Dr. Kipling W. Will (Berkeley, California) for digital images of many pterostichines discussed in this paper and to Dr. Gyõzõ Szél (Hungarian Natural History Museum, Budapest) for his kind answer to my questions concerning some characters of the holotype of Caelostomus kaszabi. This study was funded by the Presidium of the Russian academy of sciences, Program No.41 "Biodiversity of natural systems and biological resources of Russia".

\section{References}

Andrewes H.E. 1920. Papers on Oriental Carabidae, IV // Ann. Mag. Nat. Hist. Ser.9. Vol.5. P.445-455.

Andrewes H.E. 1921b. The fauna of an island in the Chilka Lake // Rec. Ind. Mus. Vol.22. Pt.4. No.23. P.339-348.

Andrewes H.E. 1930. Catalogue of Indian Insects. Calcutta: Government of India. XXII+389+4 pp.

Andrewes H.E. 1933. A Catalogue of the Carabidae of Sumatra // Tidschr. Entomol. Jg.76. S. 319-382.

Andrewes H.E. 1937b. On a collection of Carabidae from the Island of Bali // Bull. Ann. Soc. Ent Belg. T.77. P.37-46.

Andrewes H.E. 1940. Papers on Oriental Carabidae. - XXXVI // Ann. Mag. Nat. Hist. Ser.11. Vol.5. P.536.

Andrewes H.E. 1947. Entomological results from the Swedish Expedition 1934 to Burma and British India // Arkiv zool. Bd.38A. No.20. P.1-49. Pl.1-6.

Bates H.W. 1873. On the Geodephagous Coleoptera of Japan // Trans. Ent. Soc. Lond. P.219-322.

Bates H.W. 1892. Viaggio di Leonardo Fea in Birmania e regione vicine. XLIV. List of the Carabidae // Ann. Mus. Stor. Nat. Genova. Ser.2. Vol.12. No.32. P.267-428.

Darlington P.J. 1962. The Carabid beetles of New Guinea Part I. Cicindelinae, Carabinae, Harpalinae through Pterostichini // Bull. Mus. Harvard. V.126. No.3. P.321-564.

Guéourguiev B.V. 2013. On five species of the tribes Abacetini and Pterostichini(Coleoptera, Carabidae)//ZooKeys. Vol.352.P.3550. doi:10.3897/zookeys.352.6294.

Habu A. 1981. Female genitalia of Pterostichini species mainly from Japan (II) (Coleoptera, Carabidae) // Ent. Rev. Japan. Vol.36. No.1. P.33-53

Jeannel R. 1948. Coléoptères Carabiques de la Région Malgache. (Pt.2). Faune de l'Empire Français. T.10. Paris. P.373-765.
Jedlička A. 1936. Cosmodiscus rufolimbatus sp. n. // Časopis Česk. Spol. Ent. Vol.33. P.103.

Jedlička A. 1954. Neue Carabiden aus der Sammlung des Ungarischen Naturwissenschaftlichen Museums in Budapest (Coleoptera) // Ann. Hist.-Nat. Mus. Nat. Hung. T.5. S.225-229.

LaFerté-Sénectère F.T. de. 1853. Catalogue des carabiques recueillis par M. Bocandé dans la Guinée Portugaise, avec la description sommaire des espèces nouvelles // Rev. Mag. Zool. Sér.2. T.5. P.368-380.

Macleay W.S. 1825. Number 1 of Annulosa Javanica, or an attempt to illustrate the natural affinities and analogies of the insects collected in Java by Thomas Horsfield, M.D. F.L. \& G.S. and deposited by him in the museum of the honourable East-India Company. London: Kingsbury, Parbury \& Allen. P.I-XII, 1-50. P1.1.

Péringuey L. 1926. Descriptions of new species of Carabidae (Coleeoptera), with notes and additional localities of some already known species // Ann. South Afr. Mus. Vol.23. P.579-659.

Schmidt-Göbel H.M. 1846. Faunula Coleopterorum Birmaniae, adjectis nonnulis Bengaliae indigenis. P.I-VIII, 1-94. P1.I-III.

Sloane T.G. 1907. Studies in Australian Entomology. No.15. New genera and species of Carabidae, with some notes on synonymy (Clivinini, Scaritini, Cuneipectini, Trigonotomini and Lebiini) // Proc. Linn. Soc. N. S. Wales. Vol.32. P.346-381.

Straneo S.L. 1938a. Le genre Metabacetus Bates [Coleoptera, Harpalidae] // Rev. Franç. Ent. Vol.5. P.151-158.

Straneo S.L. 1938b. Studi delle specie orientali del genere Caelostomus Macl. (Coleopt. Carabid.) // Ann. Mus. Stor. Nat. Genova. Vol.60. P. 5-100.

Straneo S.L. 1940. Sulla posizione sistematica del generi Cosmodiscus Sloane e Celioschesis Tschit. (Coleopt. Carabid.) // Ital. J. Zool. Vol.11. No.1. P.211-217. doi:10.1080/11250004009437895.

Straneo S.L. 1951. Su alcuni Pterostichini nuovi o poco conosciuti del Congo belga// Rev. Zool. Bot. Afr. Vol.44. No.3. P.236242.

Straneo S.L. 1982. Considerazioni sulla posizione sistematica di alcuni generi di Pterostichini delle varie regioni dell'Africa Centrale (Coleoptera Carabidae) // Atti Mus. Stor. nat. Milano. Vol.123. Nos.2-3. P.337-341.

Straneo S.L. 1983. Revisione del genre Aristopus Laferte (Coleoptera, Carabidae)// Rev. Zool. Bot. Afr. Vol.97. No.2. P.313336.

Straneo S.L. 1995. Les genres Inkosa Péringuey, Celioinkosa Straneo et Oodinkosa Straneo et description de deux espèces nouvelles (Coleoptera, Carabidae, Pterostichini) // J. Afr. Zool. Vol.109. No.3. P.185-191.

Tschitschérine T. 1898. Matériaux pour servir à l'étude des feroniens. IV // Horae Soc. Ent. Ross. T.32. P.1-224.

Tschitschérine T. 1899. Mémoire sur quelques Platysmatini nouveaux ou peu connus, d'Afrique et de Madagascar // Ann. Soc. Ent. Fr. Vol.68. P.50-82.

Tschitschérine T. 1902. Notice sur le genre Pioprosopus Tsch. (Coleoptera, Carabidae) // Rev. Rus. Ent. No.1. P.39-40.

Will K.W. 2020a. Phylogeny and classification of the genus-group taxa of Loxandrina (Coleoptera, Carabidae, Abacetini) // Dtsch. Entomol. Z. Bd.67. No.2. P.151-182. https://doi.org/10.3897/ dez.67.55985.

Will K.W. 2020b. Review and new species of Tiferonia Darlington, 1962 (Carabidae, Abacetini) // ZooKeys Vol.906. P.131-140. https://doi.org/10.3897/zookeys.906.48255.

Will K.W., Park J.K. 2008. A new species of the oriental abacetine genus Metabacetus Bates, 1892 (Coleoptera: Carabidae) and a key to the species of the genus // Coleopt. Bull. Vol.62. P.189196. https://doi.org/10.1649/980.1. 